\title{
Mistisizmin Felsefî Okuması: Walter T. Stace'in Mistik Tecrübeye İlişkin Düşüncelerinin Bir Değerlendirmesi*
}

\author{
Betül Akdemir Süleyman**
}

\section{A Philosophical Reading of Mysticism: An Evaluation of Walter T. Stace's Views on Mystical Experience}

This article contains an assessment of Walter T. Stace's ideas on mystical experience. Walter T. Stace is undoubtedly one of the pioneering names of the twentieth century. Stace offers a philosophical reading of issues including the origins of religion, the existence of God and the possibility of religious experience, which came to the fore after Kant. He sets experience free from religion and makes it a problem regarding the nature of mankind. Through a phenomenological examination of mystical texts, he asserts that one form of mystical experience, called "introverted mystical experience," is the experience of "pure consciousness," during which unity with the "Universal Ego" is experienced. On the basis of this assertion, he proposes various conclusions regarding mysticism. However, with a keen eye, it is seen that Stace's explanations do not directly depend on the phenomenological readings of mystical texts, and behind the classification and definition of experience there also exists a philosophical hypothesis regarding consciousness. In fact, Stace acknowledges the transcendental ego, which is primordial to the constituents of experience in Kant's metaphysical system; by acknowledging this, he designates mystical experience as the experience of the transcendental ego. However, he does not ground his ideas about the transcendental ego and pure consciousness or clarify his references to Kant. Rather, he puts a spotlight on mystical narratives. By emphasizing similar terminology used by mystics, he claims them to be evidence for the experience of pure consciousness. Such a manner causes some ambiguousness in his system and weakness in the philosophical foundation of his argument. In this article, these points, which most of the time escape the attention of the reader, are underscored.

Key words: Walter T. Stace, mystical experience, unity, pure consciousness, transcendental ego.

* Makalenin yazım sürecine destek olan ve makaleyi okuyarak katkıda bulunan Prof. Dr. Rahim Acar'a teşekkür ederim.

** Dr., Din Felsefesi (betul2007@yahoo.com). 


\section{Giriş}

Walter T. Stace düşüncelerini mistisizmle ilgili çağdaş tartışmaların oluştuğu bir dönemde geliştirmiştir. Zira mistik tecrübenin farklı zaman dilimlerinde dünyanın farklı bölgelerinde, bağımsız sosyokültürel yapılarda ve birbirinden habersiz kişiler arasında meydana gelmesi, değişen felsefî paradigmalara rağmen konuyu önemli hale getirmiştir. XVIII ve XIX. yüzyılın katı akılcı tavrının etkisinin azalmasıyla birlikte, mistisizm XX. yüzyılda yeniden felsefî tartışmalarda yer almaya başlamıştır. Mistik tecrübenin ne olduğu, felsefî, epistemolojik, dinî ve ahlâkî değeri ile ilgili hatırı sayılı çalışmalar yayımlanmıştır. Bunlardan akla ilk gelenler arasında William James'in The Varieties of Religious Experience: A Study in Human Nature (1902) adli eseri vardır. James gündelik / rasyonel / normal bilinçten ince bir şekilde ayrılmış tamamıyla farklı bilincin potansiyel biçimleri olduğunu kabul etmiş ve mistisizme ayırdığg özel bölümde de dinî tecrübenin kökeni olarak gördüğü mistik tecrübeyi normal bilincin ötesine geçiş olarak tanımlamıştır. ${ }^{1}$ Evelyn Underhill, Mysticism: A Study in Nature and Development of Spiritual Consciousness (1911) başlıklı eserinde, mistik tecrübeyi "nihaî gerçeklik ile karşılaşma”, "Mutlakla bir olma” şeklinde tanımlamıştır. ${ }^{2}$ Ardından, "Kavranabilen bir Tanr1, Tanrı değildir” diyen Rudolf Otto, The Idea of Holy'de (1917) dinin sert bir şekilde eleştirildiği bir dönemde, tecrübe üzerinden dini temellendirmeye çalışmıştır. ${ }^{3}$ O, Tanrı ile insan arasındaki ilişkiyi, hiçbir kavramın ya da ayırımın aracılık etmediği (bu sayede Kantçı eleştirilere kapalı) bir "birlik" tecrübesiyle yeniden ikame etmeyi denemiştir. Böylece XX. yüzyılda Ortaçağ’da teolojinin gözdesi olan mistisizm bilinç, "vasıtasız tecrübe, 'birlik' tecrübesi, 'mutlak' ile birleşme, dinin özü” gibi kavramlar etrafında tartışmalara konu olmuştur.

Stace de Mysticism and Philosophy'de ${ }^{4}$ (1960), çoğu defa “anlaşılması zor" şeklinde nitelendirilen mistik tecrübeye ilişkin pek çok sorunu felsefî açıdan ele almış ve öncekilere kıyasla daha sofistike argümanlar geliştirmiştir. Stace'in mistisizmle ilgili sorunlara sunduğu çözüm önerisi birkaç açıdan önemlidir. Bunlardan ilki kullandığg yöntemle ilgilidir. Stace, mistik tecrübeyi teolojik ya da felsefî bir argümana göre değil, fenomenolojik olarak ele almayı tercih eder. Daha önce yapılmış çalışmalardan farklı olarak mistik tecrübenin kendisinden yola çıkarak onun özüne ulaşmayı ve mahiyetini

James, The Varieties of Religious Experience, s. 290-327.

2

Underhill, Mysticism, s. 70.

Otto, The Idea of Holy = Türkçe'si: Kutsal'a Dair, s. 57.

4 Walter T. Stace, Mysticism and Philosophy = Türkçe'si: Mistisizm ve Felsefe, çev. Abdüllatif Tüzer, İstanbul: İnsan Yayınları, 2004. 
anlamayı amaçlar. Yani tecrübeyi felsefî bir teoriye göre ele almaz. Bu amaçla o, pek çok mistik tecrübe anlatısını, tecrübeyi anlatmak için kullanılan ifadeleri derinlemesine inceler. Mistiklerin, tecrübelerine dair ifadelerinde tecrübeye sonradan eklendiğini düşündüğü yorumları parantez içine alarak, fenomenolojik indirgeme yapar. ${ }^{5}$ İkincisi, incelemeleri neticesinde farklı din, dil, kültür ve tarihte ortaya çıkan mistik tecrübeler arasında fenomenolojik bir sınıflandırmaya ulaşır. Bu sınıflandırmaya göre, iki türde mistik tecrübe vardır: "Dişa dönük" (extrovertive) mistik tecrübe ve "içe dönük" (introvertive) mistik tecrübe. ${ }^{6}$ Üçüncüsü, içe dönük mistik tecrübeyi duyusal tecrübenin bütün sınırlarını aşan, hiçbir ikilik ya da ayırım içermeyen, "evrensel ben" ile birliği içeren saf bilinç tecrübesi olarak tanımlar. ${ }^{7}$ Son olarak, saf bilinç tecrübelerinin ortak öze sahip olduğunu iddia ederek, meydana gelen tecrübeler arasında bir ortaklık tesis eder. ${ }^{8}$ Bu sayede mistik tecrübe olgusunu insanın doğasıyla ilgili evrensel bir probleme dönüştürür. Ardından mistisizmle ilgili problemleri bu iddialar çerçevesinde ele alır.

Mistisizm araştırmacıları için Stace'in yukarıda bahsi geçen iddiaları bugün hâlâ önemli ve belirleyicidir. Çünkü "birlik" tecrübesinin ortak bir öze sahip olduğu iddiasıyla Stace, hem kültür, dil, din, tarih ve en genelde de içsel ve dışsal farklılıkları aşan bağlamlar üstü bir tecrübenin imkânını kabul eder, hem de tecrübenin dile aktarılması, kavramsallaştırılması, tecrübeler arasındaki farklılıklar, dinle ilişkisi gibi konuya ilişkin pek çok problemi bu sinıflandırma üzerinden cevaplandırır. Böylece o, tecrübenin kendisinden yola çıkarak ortak özünü ve bu öz üzerinden mistik tecrübenin felsefî sorulara verdiği cevapları ortaya çıkarmış olur. XX. yüzyıl söz konusu olduğunda "mistisizmin felsefî okuması" hem mistik tecrübenin "irrasyonel" veya "saçma" olduğu söyleminin etkisini kaybetmesinde önemli rol oynar, ${ }^{9}$ hem de daha sonraki çalışmaların rengini belirler. Öyle ki 1980'lere gelindiğinde artık mistik tecrübenin ne olduğu, türleri ve özellikleri çoğu defa Stace'in

Stace, Mistisizm ve Felsefe, s. 29-36.
Stace, Mistisizm ve Felsefe, s. 61-124.
Stace, Mistisizm ve Felsefe, s. 84-124.
Stace, Mistisizm ve Felsefe, s. 84-124.

Önermelerin doğruluk değerinde bilimsel ölçütü temele alan B. Russell, bilimsel ölçütün mistiklerin tecrübeleri hakkında söyledikleri şeylere uygulanamadı̆̆ı, bu sebeple bu türden ifadelerin epistemolojik bir değerlendirmesinin yapılamayacağını düşünür. Ardından mantıkçı pozitivist olan ve Russel'dan etkilenen A. J. Ayer, epistemolojik değerlendirmede "doğrulanabilirlik ilkesi”ni ölçüt olarak kabul eder. Ayer’e göre, mistiğin tecrübesine dayanarak öne sürdüğü önermeler, bu ölçütü sağlamadığı için anlamlı olmayan önermelerdir (Bk. Russell, Din ile Bilim, s. 103-10; Ayer, Language Truth and Logic, s. 40, 123-24). 
argümanlarına göre tartışılır. ${ }^{10}$ Dolayısıyla Stace'in çağdaş mistisizm tartı̧̧malarında özel bir yeri vardır. Zaten bugün mistisizmle ilgili araştırmalarda adına en sık rastlanan isimlerden biri kuşkusuz Stace’tir.

Bu makale Stace'in yaptığ gibi, "Mistik tecrübenin fenomenolojik soruşturmasılyla tecrübe hakkında konuşmak, tecrübenin mahiyetini anlamak ve felsefî değerini ortaya çıarmak mümkün müdür?” sorusu temelinde Stace'in düşüncelerinin bir değerlendirmesini içermektedir. Bunun için öncelikle Stace'in mistik tecrübeyle ilgili açıklamalarına ve takip ettiği yönteme yer verilecek, ardından ikinci kısımda Stace'in bilinçle ilgili görüşleri, felsefî çizgide bu görüşlerin kaynağı ve onları mistisizme uygulaması ele alınacaktır. Son kısımda ise çerçevesi az çok belirginleşen Stace'in mistisizme ilişkin görüşlerinin bir değerlendirmesi sunulacaktır. Bu değerlendirmeyle Stace'in mistisizmin felsefî okumasını yalnızca mistik anlatılara dayanarak gerçekleştirmediği, düşüncelerinin arkasında bilinçle ilgili kabul ettiği felsefî teorinin yer aldığı ortaya çıkacaktır. Stace, Kant’a referansla tecrübenin unsurları$\mathrm{n} ı$ önceleyen "aşkınsal ben"i kabul eder. Mistik tecrübenin de bu "aşkınsal ben" in tecrübesi olduğunu iddia eder. Bu iddia ile mistisizm dinden bağımsızlaşır ve mistik tecrübe de bir tür entelektüel tecrübeye dönüşür. Böylece mistisizm felsefenin derin tartışmalarının konusu haline gelir. Ancak Stace, düşüncelerinin temeline yerleştirdiği bilinçle ilgili kabullerini yeterince temellendirilmez. Oysaki Kant'ın tecrübe edilemez dediği "aşkınsal ben"in tecrübesinin nasıl mümkün olduğu, mistik tecrübenin de niçin "aşkınsal ben" in tecrübesine karşılık geldiği konunun merkezinde yer alan sorunlar arasındadır. Fakat Stace, bunlarla ilgili açıklama yapmaz. Bu durum, güçlü gibi görünen bir açıklama modelinin gücünü zayıflatır. Bu sonuçla, mistisizmle ilgili sorunların bu açılama modeli üzerinden tatmin edici cevaplara ulaşmadığı ve hâlâ cevap beklediği gerçeği de ortaya çıar.

\section{Mistik Tecrübenin Fenomenolojik Tanım ve Sınıflandırılması}

Stace'e göre, mistisizmle ilgili bir araştırmada cevaplanması gereken ilk soru tecrübenin mahiyetine ilişkindir. Çünkü mistik tecrübenin tanımı ve mahiyeti, konunun uzun geçmişi ve devâsâ literatürüne rağmen bugün hâlâ

10 Meselâ Stace’in çalışmasının yayımlanmasından kısa bir süre sonra (1966 sonrası) Türkiye'de doğrudan mistisizm üzerine yapılan çalışmalara bakıldığında mistik tecrübenin tanımlarında ve türlerinde Stace'in etkisi açıkça görülür. Cavit Sunar, mistisizmi ele aldığı eserlerinde, konuyu Stace'in çizgisinde değerlendirir (Bk. Cavit Sunar, Mistisizmin Ana Hatları; a.mlf., Mistisizm Nedir?). Konuya ilişkin detaylı bilgi için bk. Betül Akdemir, "Mistik Tecrübenin Özüyle İlgili Çağdaş Kuramlar Bağlamında Türkiye'de Mistik Tecrübe Çalışmaları”, s. 72-80). 
tartışma konusudur. Zira hem mistiklerin kendileri hem de konunun uzmanları birbirinden farklı tanımlamalarda bulunur. ${ }^{11}$ Bu bakımdan Stace, normal ya da olağan tecrübeden "mistik" nitelemesiyle ayrışan bir tecrübe türünün felsefî değer ve öneminin ortaya çıkmasının, bu tecrübenin mahiyetinin, sınırlarının ve varsa sınıflarının tespitine bağlı olduğunu düşünür. ${ }^{12}$ $\mathrm{Bu}$ noktada öncelikle, mistik tecrübenin öznel psikolojik bir fenomen mi olduğu ya da öznenin bir yanılsamasını mı yansıttığı veya tıpkı duyu tecrübesi gibi öznenin dışında gerçek bir nesnesi olan bir tecrübe türü mü olduğu açıklama bekler. ${ }^{13}$

Ancak konu mistik tecrübe olduğunda yukarıdaki soruları cevaplamak hiç de kolay değildir. Konunun kendi yapısı araştırmacının karşısına birtakım zorluklar çıkarır. Karşılaşılan ilk zorluk, tecrübe anlatıları arasındaki çeşitlilikten kaynaklanır. Tarihin farklı kesitlerinde değişik kültürel, tarihî ve sosyal yapılara bağlı birbirinden bağımsız mistikler, tecrübelerini dile getirirken oldukça farklı ifadeler kullanmışlardır. Başka bir deyişle her ne kadar olağan tecrübeden farklı bir tecrübe yaşadıkları konusunda ağız birliği yapsalar ve kimi zaman benzer anlatımlarda bulunsalar da, mistiklerin tecrübenin kendisine dair açıklamaları çeşitlilik gösterir. Meselâ Budist bir mistik, tecrübesini bütün varlığın içinde yok olduğu nirvana; bir traoist ya da doğa mistiği ise doğa ile birleşme; yahudi bir mistik Tanrı ile en yakın olduğu bu anı dekuth; hıristiyan bir mistik ilâhî birlik; müslüman bir mistik ise fenâ olarak adlandırır. Dahası söz konusu bu farklılıklar yalnızca dilsel ifadelerle sınırlı kalmayıp bunlara, mistiğin sahip olduğu özellikle Tanrı̉nın varlığı ve doğası hakkındaki inançlarında, "bu dünya" ve "ötesi”ne ilişkin değerlendirmelerinde, tecrübeye ulaşmak için başvurduğu pratiklerde, kabul ettiği ahlâkî kural ve davranışlarında da rastlanılır. ${ }^{14}$ Benzerliklerin yanında farklılıkların olması, evrensel, ortak bir tecrübe türü olduğu düşüncesine şüphe düşürürken, gözlemlenen benzerliklerin gerçek benzerlikler yerine dil ailesi benzerliği olması ihtimalini akla getirir. Zira tecrübenin kendine özgü bir doğasından veya evrenselliğinden bahsedilebilmesi için farklı geleneklerde rastlanan tecrübelerin ve tecrübeyle ilişkili süreç ve ifadelerin aynı ya da benzer olması gerekir. Dolayısıyla tecrübenin mahiyetine açıklık kazandırılırken bu farklılıklar ve farklılıklar arasında tecrübeyi tanımlamaya imkân veren nasıl bir ortaklık olduğu sorusu açıklama bekler. Bu bakımdan mistik tecrübeyi tanımlama girişimi şu türde soruları cevaplamayı gerektirir:

11 Kavramın tarihsel serüveni için bk. Bouyer, "Mysticism”, s. 42-53.

12 Stace, Mistisizm ve Felsefe, s. 12-13.

13 Stace, Mistisizm ve Felsefe, s. 12-13.

14 Gimello, "Mysticism in Its Contexts", s. 61. 
Tecrübenin olağan tecrübeden farklı bir doğasının kabulü ile tecrübe anlatıları arasındaki farklılık nasıl izah edilebilir? Mistisizm dünyanın her yerinde aynı mıdır? Yoksa gelenekten geleneğe, kültürden kültüre göre çeşitlenmekte midir? ${ }^{15}$ Ya da mistik tecrübeler arasında gözlemlenen benzerlikler yalnızca dilsel aile benzerliği türünden bir benzerlikten mi ibarettir? Veya Stace'in dediği gibi, "Bütün mistik tecrübelerde ortak olan ve onları diğer türlü tecrübelerden ayıran ve dolayısıyla onların ortak özünü oluşturan bir ana özellik veya özellikler kümesi var mıdır?"16

Konuya ilişkin karşılaşılan ikinci zorluk, araştırmanın yöntemi ile ilgilidir. Zira her şeyden önce araştırılan konu bireysel bir tecrübeye dayanır. Mistik tecrübenin anlamsızlığı ile ilgili iddiaların pek çoğunda da bu husus öne çıkarılır. Kendisi bu türde bir tecrübe yaşamamış bir araştırmacıdan, bir tarafta mistisizm hakkında öne sürülen çeşitli iddialar, diğer tarafta da mistiklerin birbirinden farklı ifadeleri karşısında konuya nasıl yaklaşacağ ve yukarıdaki soruları hangi yöntemle cevaplayacağını belirlemesi beklenir. Yani konu mistisizm olduğunda, yöntem daha da önem kazanır. Peki kendisi mistik olmayan Stace, tecrübenin mahiyetiyle ilgili yukarıdaki soruları cevaplarken nasıl bir yöntem kullanmayı tercih eder? Bahsi geçen zorlukların üstesinden nasıl gelir?

Stace, ilginç bir şekilde, daha önce yapılmış çalışmaların kendisine yardımcı olmayacağını düşünür ve "Sorunla ab inito uğraşmak zorundayız" der. Hemen ardından da kendi yöntemine değinir: "Bunu yapmanın tek bir yolu vardır. Tecrübelerin mistiklerce yapılan bir dizi temsili tasvirini, olabildiğince geniş ölçüde farklı olan bütün tarihsel zamanlar, yerler ve kültürlerden alarak aktarmalıyız ve bu tasvirleri inceleyerek, eğer varsa, tümevarımsal olarak ortak ana niteliklerine varmaya çalışmalıyız." ${ }^{17}$ Stace'in "Tümevarımsal olarak ortak ana nitelikleri” ile ne kastettiği ise şu sözlerinde açıklık kazanır: "Ancak 'mistik' terimi büsbütün bulanık bir terim olduğu için, önce gözlemsel (empirically) olarak ne tip ve ne tür deneyimlere mistik dendiğini saptamak, bunların ana özelliklerini belirlemek ve sınıflamak, sınıfa ait sınırları belli etmek ve ilgisiz tipleri dışta bırakmak için alanı araştırmamız gerekiyor. Ardından, seçilen ve tanımlanan bu deneyimin ya da zihin hallerinin şu gibi sorunlara ışık tutup tutmadığını soruyoruz: ..." ${ }^{18}$

15 Forman, "Introduction", s. 3.

16 Stace, Mistisizm ve Felsefe, s. 42.

17 Stace, Mistisizm ve Felsefe, s. 43 (Vurgu eklenmiştir). (A. Tüzer'in tercümesinden yararlanmakla birlikte, "cultural" kelimesini "ekin" değil, "kültür" olarak tercüme etmeyi tercih ettik (Bk. Stace, Mysticism and Philosophy, s. 45).

Stace, Mistisizm ve Felsefe, s. 7 (A. Tüzer'in tercümesinden yararlanmakla birlikte, 
Yukarıdaki ifadelerinden anlaşıldığına üzere Stace, mistik tecrübeye ilişkin felsefî soruşturmasını herhangi bir varsayımdan hareketle ya da belirli bir felsefî kurama göre değil, tecrübenin kendisine dayandıracağını, tecrübeye dair ifadelerden onun tanımına, varsa tecrübeler arasındaki ortak özelliklere ve farklılıkların çözümüne ulaşacağını iddia eder. Çünkü o, herhangi bir indirgemenin oluşmaması için "tümevarım” $ı$ bu konuyu soruşturmanın yegâne yolu olduğunu düşünür. Bu bakımdan Stace’in projesi mistisizmin kendi iç dinamiklerinden yola çıkarak fenomeni anlamayı ve varsa felsefî sorunlara sunduğu cevapları bulmayı içerir. Peki Stace mevcut çalışmaları "yargıları az çok gelişigüzel"19 diye nitelendirip, onlara başvurmayı reddederken, fenomenin kendisinden yola çıkarak hangi cevaplara ulaşır? Mistik tecrübe anlatıları, tecrübenin kendisi hakkında ne tür bilgiler içerir? Düşünür, fenomenolojik yöntemle daha önce bahsi geçen mistik tecrübenin mahiyeti ve tecrübeler arasındaki farklılıktan kaynaklanan sorunları nasıl çözümler?

Stace ilk olarak, olağan tecrübeden farklı olan ve "mistik" şeklinde nitelendirilen bir tecrübe türünün olduğunu tartışmaya girmeksizin kabul eder. ${ }^{20}$ Bunu şöyle dile getirir: “... Onun birkaç nâdir insanda bulunması, hakkında bol miktarda delil bulunan psikolojik bir olgudur. Onun psikolojik bir olgu olarak mevcudiyetini reddetmek veya ondan şüphe etmek, saygı duyulacak bir görüş değildir. $\mathrm{Bu}$ bir cehalettir." ${ }^{21}$ Stace’in bu kabulünde tecrübenin yaygınlı̆̆ından ziyade ampirizme yakın olması etkilidir. Ona göre, tecrübe epistemolojinin temelindedir. ${ }^{22}$ Tecrübenin kendisi için başka bir delil ya da gerekçelendirme mevcut değildir. ${ }^{23}$ Dolayısıyla bir tecrübe türü olan mistik tecrübenin olgusal olarak mevcut olması bir delil ya da gerekçe gerektirmez.

Stace, mistik tecrübenin kabulünün ardından, tecrübenin olağandışı durumlar ya da hastalık halleriyle ilişkilendirilmesini eleştirir. "Mystic" kelimesinin "gizem, büyü, sır" gibi anlamları işaret etmesinden yola çıkılarak mistik tecrübenin, sihirbazlıkla, okültizmle, spiritüalizmle veya telepati, telekinezi, kehanet, sezgi gibi parapsikolojik olaylarla ilişkili olduğu iddia edilir. ${ }^{24} \mathrm{Her}$ ne kadar kimi zaman mistiklerin ifadeleri bu tarzda yorumlamalara kapi

"empirically" kelimesini, "deneysel" yerine "gözlemsel" olarak tercüme etmeyi tercih ettik (Bk. Stace, Mysticism and Philosophy, s. 9).

19 Stace, Mistisizm ve Felsefe, s. 43.

20 Stace, Mistisizm ve Felsefe, s. 43.

21 Stace, "Mistiklerin Öğretileri", s. 119.

22 Stace, The Theory of Knowledge and Existence, s. 30-45.

23 Overall, "Mysticism, Phenomenalism, and W. T. Stace", s. 178-82.

24 Stace, The Teachings of the Mystics, s. 10, 11. 
aralayacak bazı öğeler içerseler de, Stace’e göre, mistik tecrübe bütünüyle farklı bir tecrübe türüdür.

Stace, artık yapılan yanlış ilişkilendirmeler ve indirgemeleri dışarıda bırakıp, mistiklerin de yalan söylemediğini kabul ederek konuya bakar. Böylece, onun ikinci kabulü ortaya çıar. Ona göre, mistik tecrübe, gündelik / olağan tecrübeden farklı, duyumsal-zihinsel olmayan, ikilik / farklılık içermeyen bir bilinç türüdür. ${ }^{25}$ “... Mistik tecrübelerin paylaştığı ve nihaî tahlilde, onları tanımlayan ve diğer tecrübelerden ayıran temel nitelikler, onların ne duyuların ne de aklın nüfuz edebildiği tüm eşyadaki duyusal olmayan nihai bütünlük, birlik ve Bir hakkında kavrayışı içermesidir. Başka bir ifadeyle, o, bizim duyusal-zihinsel bilincimizi bütünüyle aşar."26 Mistikler, farklıllklara rağmen, mistik tecrübenin "birlik"in algılanması veya dolaysız kavranması olduğunda ağız birliği yaparlar. ${ }^{27}$ Stace, söz konusu ağız birliğinden mistik tecrübenin ana kavramının "birlik" veya "bir" olduğu sonucuna ulaşır. Tecrübeye ilişkin bu belirlemenin ardından, ses ve görüntü gibi duyusal öğeler içeren tecrübeleri (Aziz Paul'un Şam yolunda gördüğü ışık ve duyduğu, "Paul! Paul! Niçin bana eziyet ediyorsun?” şeklindeki sesi, yine Azize Terasa’nın Îsâ ile ilgili görüntüleri gibi) bu fenomenin dışında tutar. ${ }^{28}$ Başka bir deyişle o, mistik tecrübeyi ses ve görüntü gibi duyusal unsur içermeyen "birlik" tecrübeleriyle sınırlandırır. ${ }^{29}$

Metinlere artık bu gözle bakan Stace'in, "birlik" tecrübeleri arasında iki farklı düzey olduğu dikkatini çeker. Birlik tecrübesine dair ifadelerin bir kısmında duyusal unsurlar ağırlıklıdır ve mistik dışta var olanların birliğini tecrübe ettiğini söyler. Bunun yanında kimi anlatılarda ise hiçbir duyusal

25 Stace, The Teachings of the Mystics, s. 10, 11.

26 Stace, "Mistiklerin Öğretileri", s. 119, 120.

27 Stace, Mistisizm ve Felsefe, s. 64, 65.

28 Stace, Mistisizm ve Felsefe, s. 45-49.

29 Stace'in bu sinıflandırması R. Swinburne'ün tasnifindeki en son aşamayı hatırlatır. $\mathrm{Bu}$ tasnife göre beş tür tecrübe vardır: 1. "Sıradan, herkesçe bilinen bir duyu nesnesi vasıtasıyla, Tanrı’nın veya "mutlak gerçek"in tecrübe edilmesi (gün batımı esnasında okyanusta Tanrı’yı görmek gibi). 2. Sıra dışı ve herkesçe bilinen bir duyu nesnesi vasıtasıyla Tanrı’nın veya "mutlak gerçeklik"in tecrübe edilmesi (Hz. Mûsânın çalılıkta gördüğü ateş, bu ateşi herkes görebilir ancak sadece Hz. Mûsâ yanan fakat kül olmayan bir çalılık gördügünü iddia etmiştir). 3. Kişiye mahsus ve normal duyu diliyle tasvir edilebilen duyumlar vasıtası ile Tanrı'nın veya "mutlak gerçeklik" in tecrübe edilmesi (bir rüyada veya hayalde Tanrı’yı görme iddiası). 4. Kişiye mahsus fakat normal duyu diliyle tasvir edilemeyen duyumlar vasitası ile Tanrı'nın veya "mutlak gerçeklik"in tecrübe edilmesi (hakkında konuşulamaz ya da ifade edilmez bir tecrübe). 5. Hiçbir duyum vasıtasına dayanmaksızın Tanrı'nın veya "mutlak gerçeklik"in tecrübe edilmesi” (Bk. Swinburne, The Existence of God, s. 249-52). 
içeriğin olmadığı, saf bir birlik tecrübesinden söz edilir. Stace, bu farklıllğın yalnızca dilsel ifadeden kaynaklanmadığını düşünür ve bu ayırımı temel alarak mistik tecrübenin iki ana türünün olduğunu öne sürer. "Bir"in kavranış1 olan bu tecrübeler, dışa dönük mistik tecrübe ile (extrovertive mystical experience) içe dönük mistik tecrübedir (introvertive mystical experience). ${ }^{30}$ Ardından Stace araştırmasında bu iki tür üzerinde yoğunlaşır. Şimdi sırasıyla bu sinıflandırmanın detaylarına yer verilecektir.

Stace, dışa dönük mistik tecrübeyi "birlik"in dış dünyada var olanlarda algılanması olarak tanımlar. Yani bu tecrübe türünde fiziksel dünyanın algılanışı devam etmekle birlikte, çokluğun gerisindeki birlik tecrübe edilir. ${ }^{31}$ Mysticism and Philosophy'de, bu tecrübeye örnek olarak M. Eckhart'ın şu ifadeleri verilir: "Bir insanın burada dışsal olarak çokluk içerisinde gördüğü şey gerçekte birdir. Burada bitki yaprakları, ağaçlar ve taşlar, her şey birdir. Bu en derin derinliktir." ${ }^{22}$ Bir diğer örnek ise Azize Terasa'ya aittir. Azize’nin ifadesi şöyledir: "Bir gün yakarışta bulunurken bir anda bana her şeyin nasıl göründüğünü ve nasıl Tanrı’da kapsandığını algılama gücü bahşedildi. Onları kendilerine özgü biçimde algılamadım, bununla beraber onlarla ilgili sahip olduğum görüş son derece açıktı ve ruhuma capcanlı kazındı." ${ }^{33} \mathrm{Her}$ iki anlatıda da görüldüğü üzere, tecrübe sahipleri olağan tecrübeden farkll, rasyonel bilinci aşan bir tecrübeden bahsederler. Stace'in dikkat çektiği husus, bu tecrübe esnasında eşyanın kendine ait özellikleri yani ağacın ağaç ve taşın taş olması gibi, algılanmaya devam etmekle birlikte, "Bitki yaprakları, ağaçlar ve taşlar, her şey birdir" ve "bana her şeyin nasıl göründüğünü ve nasıl Tanrı'da kapsandığını" ifadelerinin de işaret ettiği gibi tecrübeye "birlik" algısı eşlik eder. ${ }^{34}$ Yani hem nesnenin kendi bireysel varlı̆̆ devam eder hem de diğer nesnelerle aşkınsal bir birlik sergiler. ${ }^{35}$ Diğer bir deyişle mistik, gündelik tecrübelerde kavranmayan her şeyin ardındaki "birlik"i algılar. Yani duyusal-entelektüel zihin, üst bir zihin durumuyla birleşir. ${ }^{36}$

30 Her ne kadar Stace, öncekilerin araştırmalarından yararlanmayacağını söylese de, mistik tecrübeler arasında yaptığı içe dönük ve dışa dönük mistik tecrübe ayırımı, Rudolf Otto'nun “içe bakış" ve "birlik vizyonu” ayırımını hatırlatır (ayrıntılı bilgi için bk. Kalın, Rudolf Otto'da Din, s. 128-36).

31 Stace, Mistisizm ve Felsefe, s. 60.

32 Rudolf Otto'dan naklen Stace, Mistisizm ve Felsefe, s. 62.

33 William James'ten naklen Stace, Mistisizm ve Felsefe, s. 67.

34 Shear, “On Mystical Experiences as Support”, s. 320.

35 Stace, Mistisizm ve Felsefe, s. 71.

36 Dışa dönük mistik tecrübeye ilişkin daha detaylı bilgi için bk. Stace, Mistisizm ve Felsefe, s. 47-84. 
Tecrübenin ikinci türü "birlik"in dolaysız kavrandığı içe dönük mistik tecrübe, saf bilinç durumudur (pure consciousness event). Her ne kadar Stace dışa dönük mistik tecrübeyi varoluşun anlamını yeniden konumlandırmaya aracılık etmesi bakımından değerli görse de, birliğin dışsal nesneler üzerinden yani bir bakıma dolaylı olması sebebiyle yeterince saf bulmaz. ${ }^{37}$ Bunun yanında içe dönük mistik tecrübe için durum daha farklıdır. İçe dönük mistik tecrübe, hiçbir duyum, imgelem, his veya düşüncenin aracllık etmediği, bunlardan bağımsız tam bir birlik tecrübesidir. ${ }^{38}$ Mistik, duyusal-entelektüel bilincinin iç ve dış bütün içeriklerini bastırdığında "birlik"i dolaysız kavrar. Yani dışa dönük mistik tecrübede mistiğin "birlik"i nesneler üzerinden algılamasından farklı olarak içe dönük mistik tecrübede birlik, mistiğin kendi bilinci üzerinden ve hiçbir aracı olmaksızın algılanır. "Kezâ mistik bilinç için herhangi bir duyum diye bir şey söz konusu değildir. Ayrıca o herhangi bir kavram veya düşünce ihtiva etmez. O, duyusal-entelektüel bir bilinç değildir." ${ }^{39}$ Mistik kendi bilincinin içeriklerinden arındığında, bireyselliği çözülür ve saf bilinç ortaya çıkar ki bu gerçek birlik algısına denk düşer. Meselâ bir Budist içe dönük tecrübesini şöyle dile getirir: "Bütün karşllıklı ilişki şekillerini aşan Mutlak Boşluk... Budist boşlukta zaman, mekan, oluş, şeylik yoktur. Salt deneyimin kendini kendinde yansıtılmış olarak gören zihindir. Bu ancak zihnin kendisi boşluk olunca yani zihin kendisi dışındaki bütün olası içeriklerinden kurtulduğunda olanaklıdır." ${ }^{20}$ Zira Eckhart'ın dediğine göre, "Eğer orada (ruh) başka bir görüntü mevcut olsa idi, gerçek bir birleşme olmayacaktı." ${ }^{\prime 1}$ Stace' in bu tecrübe türüyle ilgili olarak yaptığ 1 açılamalarda dikkat çeken şey, "birlik" algısının saf bilinç durumuna eşitlenmesidir. Yani bilinç, dış dünya ile olan bağından ve kendi içeriklerinden arındığında, nesnesiz bilinç hali ortaya çıkar ki bu aynı zamanda "evrensel ben" ile birleşme anı, saf bilinç durumudur. Saf bilinç durumunun, gündelik tecrübeyle kıyaslandığında anlaşılması hayli zordur. Çünkü bahsi geçen aracılar, öznenin dışında değil bilincine içkindirler. Bu bağlamda akla şöyle bir soru gelir: Saf bilinç durumuna ulaşmanın belirli bir yolu veya kullanılan belirli bir yöntem var mıdır?

37 Stace, Mistisizm ve Felsefe, s. 47-84.

38 Stace, Mistisizm ve Felsefe, s. 6o, 61.

39 Stace, "Mistiklerin Öğretileri”, s. 118.

40 Suzuki, Mysticism: Christian and Buddhist, New York: Harper and Brothers, 1927, s. 28'den aktaran: Stace, Mistisizm ve Felsefe, s. 110, 111 (A. Tüzer' in tercümesinden yararlanmakla birlikte, "absolute emptiness" kelimesini, "saltık boşluk" olarak değil, "mutlak boşluk" olarak tercüme etmeyi tercih ettik (Bk. Stace, Mysticism and Philosophy, s. 109).

41 Eckhart, Ben, Meister Eckhart, s. 72. 
Stace bu noktada dikkatleri mistik geleneklerde rastlanılan mânevî eğitime çeker. Ona göre, mistiklerin dahil olduğu mânevî eğitim, onları bilince aşkın ve içkin bütün unsurlardan bağımsızlaştırır. Böylece mistik, gündelik tecrübenin sınırlarını aşarak evrensel gerçeği içsel, dolaysız, bütün duyumlardan ve zihinsel bilinç hallerinden âzâde olarak kavrar. ${ }^{42}$ İster Hindu, ister yahudi veya hıristiyan olsun, bu tecrübeye ulaşmayı amaçlayan kişi, genelde uzun yıllar süren, zikir, meditasyon, yoga, nefes egzersizleri gibi farklı alı̧stırmalar yapar. ${ }^{43} \mathrm{Bu}$ alıştırmalarda zihnin kendi anlamlarından bağımsızlaşması amaçlanır. Çünkü sunyata yani boşluğun tecrübesi gibi tecrübeler, "ancak zihnin kendisi boşluk olduğunda" olanaklıdır. ${ }^{44}$ Gerçekten de Stace'in dediği gibi, neredeyse her mistik geleneğin kendisine has yöntemleri vardır. Meselâ kimi geleneklerde anlamsız söz öbekleri uzun bir süre tekrar edilir. Bu türde kelimelerden oluşan bir Vedic mantrası şöyledir: "HĀ BU HĀ BU HĀ BU HĀ Ū HĀ Ü HĀ Ü/ KĀ HVĀ HVĀ HVĀ HVĀ HVĀ KĀ HVĀ HVĀ HVĀ HVĀ HVĀ KĀ HVĀ HVĀ HVĀ HVĀ HVĀ ..." ${ }^{45}$ Mistik, bilinçlilik halini yitirip saf bilinç durumuna ulaşana kadar farklı aralıklarda ve sürelerde bu kelimeleri söylemeye devam eder. Tabi ki yukarıdaki türde mantralar mânevî eğitimin yalnızca bir örneğidir. ${ }^{46}$ Bunun gibi farklı geleneklerde farklı biçimlense de, bilincin bağımsızlaşması için belirli pratiklere başvurma konusunda mistikler neredeyse hem fikirlerdir. Stace de bu ortaklıktan, hazırlık aşamasının tecrübeye ulaşmanın aracı, başka bir ifade ile yöntemi olduğunu çıkarır.

Yukarıda yer verilen açıklamalarla belirginlik kazanan iki noktanın altını çizmek gerekir. Bunlardan ilki, Stace'in içe dönük mistik tecrübeyi saf bilinç durumu şeklinde nitelemesi ile konuyu bilinçle yani insanın doğasıyla ilgili hale getirmesidir. Stace bununla ilgili şöyle söyler: “... Mistik bilinci harikulade ve doğa üstü olduğunu varsaymanın hiçbir nedeni yoktur. Şüphesiz, o, bizim sıradan bilincimiz gibi evrimin doğal süreci tarafından oluşturulmuştur." ${ }^{77}$ Yani mistik tecrübe, insanın yetenekleri arasındadır. İkincisi, hazırlık sürecini tecrübeye ulaşma aracı kabul etmesiyle, tecrübenin herkese açık olduğu düşüncesine kapı aralar. Bunun anlamı mistik tecrübe rastlantısal bir tecrübe değildir. Bu türde tecrübe yaşamak için özel yeteneklere ihtiyaç yoktur. Bu hazırlıkları başarı ile yapabilen herkes bu tür

42 Stace, Mistisizm ve Felsefe, s. 103-135.

43 Stace, "Mistiklerin Öğretileri”, s. 120, 121.

44 Stace, Mistisizm ve Felsefe, s. 110.

45 Staal, Exploring Mysticism, s. 35.

46 Eliade, Yoga, s. 40, 41.

47 Stace, "Mistiklerin Öğretileri”, s. 119. 
tecrübelere sahip olabilir. Böylece mistik tecrübe herhangi bir kişiye, topluluğa ya da dine özgü olmaktan çıar. İnsanı ilgilendiren bir probleme dönüşür. Dolayısıyla felsefenin de alanına girmiş olur.

Bu iki noktanın ardından Stace’in temel iddiası ortaya çıkar. İçe dönük mistik tecrübeler evrensel öze sahiptirler. Bu iddiaya göre, bütün kültürlerde, dinlerde, dönemlerde ve farklı sosyal şartlarda ortaya çıkan saf bilinç tecrübeleri, farklılıkların ötesinde ortak bir öze sahiptir. Yani hıristiyan mistiğin "Tanrı ile birleşme", Hindu mistiğin "evrensel ben ile özdeşleşme", müslüman mistiğin "Allah’ta fenâ" dediği tecrübe aslında içe dönük, saf bilinç tecrübesidir ve bunlar aynı özü paylaşırlar. Ortak özü paylaşmalarının anlamı aslında tecrübeler arasında özsel bir farklılığın olmadığıdır. Esasında Hindu, hristiyan, Budist, müslüman mistik, insanın doğasından kaynaklanan saf bilinç tecrübesi yaşamıştır. Böylece Stace, bir yandan mistik tecrübeyi dinden bağımsızlaştırırken, diğer yandan mistik tecrübenin bir türünün evrensel olduğunu ileri sürer. Bunun anlamı, insanın sahip olduğu bir tecrübe türünün, zamanı, mekânı ve bağlamları aşması, evrensel ortaklığa sahip olması ve dahası konusunun "evrensel ben" olmasıdır. Stace’e göre, "Bu Evrensel ya da Kozmik Ben kişi tanrıcı dinlerin Tanrı diye yorumladığı şeydir. Aynı zamanda bu Upanişadlar’ın Brahman-Atman’ıdır. Tüm deneysel içerikten yoksun olduğu için de bu Budistleri'in Boşluk'udur, Eckhart'in hiçliğidir, bütün mistiklere göre dünyanın özeğinde olan karanlık ve sessizliktir." ${ }^{48}$

Ortak öz iddiasının ardından Stace, tecrübe ve yorumu arasında bir ayırım yapar. Çünkü içe dönük mistik tecrübenin evrenselliği veya tecrübelerin ortak öze sahip olduğu iddiasının önündeki en büyük problem, mistik anlatılar arasındaki farklılıklardır. Eğer içe dönük tecrübe, dolaysız ve saf bir tecrübe ve yaşanan bütün içe dönük tecrübeler özde ortaksa, niçin Hintli bir mistik ile hıristiyan bir mistiğin veya herhangi başka bir mistiğin tecrübesi birbirinden farklıdır? Ya da ortaklığa rağmen tecrübeyi, müslüman, yahudi veya Hindu tecrübesi yapan şey nedir? Stace’e göre, farklılığın sebebi tecrübe sonrası yorumlama sürecinden kaynaklanır. Zira saf bilinç tecrübesinin kendisinde hiçbir ayırım ve ikilik yoktur. ${ }^{49}$ Başka bir deyişle içe dönük mistik tecrübe bilincin bütün unsurlarını ve içeriklerini önceleyen kendinde saf halinin tecrübesi olduğu için, bu tecrübede dilsel kategoriler de aşılmıştır. Dolayısıyla yaşanan "birlik", kavramsallaştırma faaliyetinin olmadığı, dilin aracılık etmediği, hiçbir ikilik içermeyen saf bir tecrübeye işaret eder. Ne zaman ki tecrübe tamamlanıp, gündelik bilinç durumuna dönüldügünde tecrübe, kavramsallaştırma faaliyetinin içerisinde ifade bulur.

48 Stace, Mistisizm ve Felsefe, s. 242.

49 Stace, Mistisizm ve Felsefe, s. 6o, 61. 
Stace'e göre tecrübeyi yorumlama faaliyeti de yine iki düzeyde gerçekleşir. Bunlar, doğrudan edimsel tecrübeye işaret eden "düşük düzeyli yorum" ile mistiğin kendi bireysel düşüncesi ile tecrübesini biçimlendirdiği "yüksek düzeyli yorum"dur. ${ }^{50}$ Düşük düzeyli yorum, zihnin yetilerinden kaynaklanan ve kendiliğinden gerçekleşen yani mistiğin bilinçli bir etkisinin olmadığ "kavramşallaştırma" sürecinin neticesidir. Olağan tecrübe için geçerli olan bu süreç, içe dönük mistik tecrübede de gerçekleşir. Her zaman "duyumun bir şey, kavramsal yorum"un (kavramsallaştırılmış, tecrübe edilmiş olanın) "başka bir şey olduğundan kuşku duyulmaz."51 Tecrübenin kendisinde hiçbir ayırım olmadığı için de mistik yaşadığı şeyi "boşluk, birlik, sonsuz" ya da "hiçlik" gibi genelde belirli bir anlamı olumsuzlayan ve belirli bir felsefî veya dinî gönderimi olmayan âdeta tarafsız kelimelerle tarif eder. ${ }^{52}$ “... Eğer bir mistik ayrımlaşmamış farksız birlik deneyiminden söz ederse yalnızca sınıflayıcı sözcükleri kullanan bu sade aktarım veya tasvir düşük düzeyli bir yorum olarak görülebilir. Ama bu yorum genellikle gerekenden çok daha titizlikli bir biçimde açık olur, çünkü bu tüm niyet ve amaçlara karşın yalnızca bir tasvirdir." 53

Yüksek düzeyli yorum ise, mistiğin kendi kültür, dinî ve sosyal çerçevesine göre, tecrübesinin neye benzediği veya benzemediğini düşünmesinin neticesi ortaya çıar. Söz konusu bu ikinci yorum, tamamen mistiğin etkin olduğu kısımdır. ${ }^{54} \mathrm{Bu}$ aşamada mistiğin sahip olduğu kavramlar tecrübeye eklenir ve tecrübenin âdeta kimliğini belirler. Bunun anlamı, yaşanan tecrübe hem zihnin kendi işleyişi gereği kavramsallaştırılır hem de mistiğin kavramsal çerçevesine göre ifade bulur. Stace'in ifadeleriyle, "Eğer bir mistik 'evrenin yaratıcısı ile mistik bir birleşme' tecrübesi edindiğini söylerse bu yorum saf tasviri bir anlatımdan çok daha fazla akılsal katkı içerdiği için yüksek düzeyli bir yorum olacaktır. Bu yorum, dünyanın kökenine değin bir varsayım ve bir kişisel (a personal God) Tanrı’nın varlığına inancı kapsayacaktır.” “... 'Ayrımlaşmamış birlik' sözü Tanrı̀ya ya da Mutlak’a ilişkin hiçbir referans içermez. Eğer birisi, böyle bir mistik tecrübeye dayanarak zamanın gerçek olmadığını söylüyorsa, açıkçası bu yüksek düzeyde bir yoruma sahip genel bir felsefî teorem olur." ${ }^{56}$ Dolayısıyla Stace'e göre, içe dönük mistik tecrübeyi

50 Stace, Mistisizm ve Felsefe, s. 36.

51 Stace, Mistisizm ve Felsefe, s. 30.

52 Stace, Mistisizm ve Felsefe, s. 86.

53 Stace, Mistisizm ve Felsefe, s. 38.

54 Stace, Mistisizm ve Felsefe, s. 38.

55 Stace, Mistisizm ve Felsefe, s. 38.

56 Stace, Mistisizm ve Felsefe, s. 38. 
Budist tecrübesi, hıristiyan, yahudi ya da müslüman tecrübesine dönüştüren, mistik öznenin referans çerçevesidir. Başka bir deyişle, bu türde ifadeler aslında doğrudan tecrübenin kendisine işaret etmezler. Tecrübeye sonradan eklenen yorumlar arttıkça farklılıklar da artar. Buna karşılık, "ayrımlaşmamış birlik, ışık, karanlık, birlik, hiçlik, boşluk, sessizlik" gibi tasviri ifadeler doğrudan tecrübeye aittir. ${ }^{57}$ Stace, tecrübe ve yorumu arasında yaptığı bu ayırımla, saf bilinç tecrübesinin evrensel öze sahip olduğu iddiasını güçlendirdiği gibi, tecrübeler arasında belirli tipolojilere ulaşmayı da olanaklı kılar. Çünkü Budist'in nirvana, sûfînin fenâ, hıristiyanın ilâhî birlik șeklinde dile getirdiği tecrübesi, saf bilinç tecrübesi olup, aynı öze/mahiyete sahiptir ve sonrasında kavramsal şemaya göre yorumlanmıştır. Tecrübenin özü bütün görünümlerine ve kişisel düşüncelere aşkın, indirgenemez ve saftır. Kişisel yorumlamaların ötesindedir. Yukarıda da geçen "ayrımlaşmamış birlik, ışık, karanlık, birlik, hiçlik" gibi ifadelere her kültür ve gelenekte rastlanıyor olması da bunun bir delilidir. Kısacası farklılıkların kaynağı tecrübe sonrası süreçle ilgilidir. Yani diğer bir deyişle, her ne kadar mistikler farklı bir tecrübe yaşadıkları konusunda yanılmıyorlarsa da, tecrübeye kaynaklık edenin ne olduğu konusunda kendi yorumlamalarını katmaları bakımından yanılmaktadırlar. ${ }^{58}$ Çünkü Stace'e göre, onların inandığı ve ulaşmaya çalıştıkları ontolojik gerçeklik tecrübenin kendinde yer almaz. Mistikler, tecrübe sonrasında açıklama sırasında kendi inançlarını devreye sokarlar. Yoksa içe dönük mistik tecrübelerin kendilerinde farklılık yoktur. Stace doğrudan metinler üzerinden pek çok örnekle bu iddiasını destekler.

Yukarıdaki açılama modeli ile Stace, içe dönük mistik tecrübenin dinî bir tecrübe türü olmadığı sonucuna da varmış olur. Başka bir deyişle, mistisizm dinî bir fenomen değildir. Dinlerin "tanrı"sı bu tecrübenin ne başlatıcısı ne de nesnesidir. Tecrübenin kendisinde hiçbir teolojik kategori ya da herhangi bir başka dolayım yoktur. Tecrübenin dinle ilişkilendirilmesi tamamen mistiğin bireysel inançları ile yaptığı yorumdan kaynaklanır. Yani aslında mistik, "Tanrı'da yok olma”, "Îsâ ile birleşme”, "Allah’ı müşahede etme" gibi dinî ifadeler kullanırken, aslında tecrübenin kendisine dayanmamaktadır. Hiçbir dine mensup olmayan bir kişi de bu tecrübeye sahip olabilir. Dolayısıyla mistisizm dinle birlikte bulunabilir ancak bu onun için zorunlu değildir. ${ }^{59}$ Hatta tecrübe sahibi "... yeteri düzeyde bilgili ise" "evrensel ben" ile birleşme tecrübesi sonrasında, "içerisinde bulunduğu inançtan vazgeçebilir." ${ }^{60}$ Yani Stace aslına

57 Harmless, Reading Mystics, s. 255.

58 Stace, Mistisizm ve Felsefe, s. 346.

59 Stace, Mistisizm ve Felsefe, s. 345.

60 Stace, Mistisizm ve Felsefe, s. 346. 
mistisizmi dinden bağımsızlaştırarak, mistik tecrübeyi aklın aşkınsal temeli üzerinden temellendirip felsefî / entelektüel bir tecrübeyi kabul eder. Böylece Stace mistik tecrübe konusunu dinî alandan çıkararak, F. Schleiermeacher, R. Otto, M. Buber, W. P. Alston gibi tecrübenin din dışı açıklamalarına ısrarla karşı duran XIX ve XX. yüzyıl filozof ve teologlarından da ayrılmış olur. ${ }^{61}$

Buraya kadar Stace'in, fenomenolojik yöntemle mistik tecrübe literatürünü inceleyerek, tecrübenin mahiyetine, sınıflarına, farklı bağlamlarda ortaya çıkan tecrübeler arasındaki ortaklığa, tecrübenin dil ve dinle ilişkisine yönelik felsefî açıklaması ele alındı. Gerçekten de Stace çok geniş bir tartışma alanını etkileyici bir şekilde yorumlamış, metinlerle de kendisini desteklemiştir.

\section{Saf Bilinç: Tecrübenin Aşkınsal Temeli}

Bir önceki başlıkta görüldüğü üzere Stace, mistiğin "evrensel ben" ile "birlik" tecrübesi yaşadığını iddia etmekte ve bunu saf bilinç tecrübesi olarak tanımlamaktadır. Stace'in mistisizmle ilgili açılamalarını değerlendirebilmek için bu açıklamaların temelinde yer alan bilinçle ilgili varsayımlara değinilmesi gerekir. Bu bakımdan makalenin bu kısmında Stace'in saf bilinç tecrübesi tanımındaki bilinçle ne kastettiğine, bu düşüncesinin referanslarına ve cevapsız kalan bazı sorulara değinilecektir.

İnsan tecrübesinin sınırlarına ilişkin herhangi bir tartışma, ancak benlikle ilgili belirli kabuller doğrultusunda gerçekleştirilebilir. Çünkü "ben"in tözel olup olmaması daha başlangıçta tecrübeye birtakım sınırlar çizer. Dolayısıyla mistik tecrübe, olağan tecrübeden radikal bir farklılığı îmâ edecek şekilde kullanıldığında başka bir deyişle doğrudan insan tecrübesinin imkânları ve sınırlarına ilişkin bir konu olarak gündeme geldiğinde bu, konunun benlikle ilgili sorulara da cevaplar sunduğu anlamına gelir. Peki Stace'in görüşlerinin arka planında nasıl bir özne tasarımı vardır? Başka bir ifade ile olağanın sınırlarını aşan bu "ben"in mahiyeti nedir? Saf bilinç nasıl bir özneye işaret eder?

Stace, Mysticism and Philosophy'de bilince veya saf bilince dair özel bir bölüm ayırmaz, yeri geldikçe konuya değinmeyi tercih eder. Bu bakımdan Stace'in görüşlerini saptamak oldukça zordur. Sözü edilen zorluğa rağmen, yaptığı atıflar üzerinden saf bilinci anlamaya çalışacağız. Stace, ilk olarak D. Hume'un benlik ile ilgili düşüncelerini eleştirir. Hatırlanacağı üzere XVIII. yüzyılda insanın anlama yetisi üzerine dikkatleri çeken Hume, tecrübenin

61 Ayrıca konuyla ilgili bk. Tüzer, Dinî Tecrübe ve Mistisizm, s. 37-93; Jay, Deneyim Şarklları, s. 110-73; Kalın, Rudolf Otto'da Din, s. 27-120. 
duyu verilerine bağlı olduğunu ve zihnin çağrışım ilkelerine göre biçimlendirildiğini iddia ediyordu. ${ }^{62}$ Ona göre, her türlü tecrübe gibi "ben" de izlenimlere yani algıya bağlıdır. Hume’un bu düşüncesini içeren pasaj şöyledir:

Bana kalırsa ben, benlik dediğim şeyin en yakınına girecek olursam, her zaman sıcaklık ya da soğukluğun, ş̧ık ya da gölgenin, sevgi ya da nefretin, acı ya da hazzın şu ya da bu tikel algısına çarparım. Hiçbir zaman benliğimi bir algı olmaksızın yakalayamam ve hiçbir zaman algıdan başka herhangi bir şey gözleyemem. Derin bir uyku esnasında olduğu gibi alg1larım bir süre için ortadan kaldırılacak olursa, o süre boyunca benliğimi duyumsamam ve var olmadığım hakikaten söylenebilir. ${ }^{63}$

Algıları önceleyen benlik tasarımına karşı çıktığı anlaşılan Hume, devamında şu sonuca ulaşır: Ben "kavranamayacak bir hızla birbirini takip eden ve sürekli bir akış ve hareket halinde olan farklı algıların bir demetinden ya da derlemesinden başka bir şey" değildir. ${ }^{64}$ İfadelerinden de anlaşıldığı üzere Hume, "ben"i algılar demetine eşitleyerek, onun algıları aşan, tecrübeye eşlik eden, zamanda değişmeden kalan bağımsız birliğini, doğasını başka bir deyişle tözel varlığını açıkça reddeder. ${ }^{65}$

Stace ise tecrübenin unsurlarını aşan saf bilinci kabul eder. Hume'un yukarıdaki iddiasını hatırlatarak, onu zihinsel-entelektüel bilincin bir durum ya da aşamasını bilincin bütünü kabul edip indirgeme yapmakla eleştirir. ${ }^{66}$ Stace'in bu eleştirisinin temelindeki düşünceye göre, normal bilinç görme, işitme, koklama gibi fiziksel duyumlar; duyumların zihinsel kopyaları olarak düşündüğümüz imgeler; kavramsal yetilerden meydana gelen soyut düşünme ve akıl yürütmeyi içerir. Bu yapının bütünü, zihinsel-entelektüel bilinçtir. Ancak ona göre, Hume’un iddia ettiği gibi bilinç yalnızca zihinsel-entelektüel bilinçten ibaret değildir. Stace bu iddiasını desteklemek için şu soruyu sorar: "Herhangi birinin duyumların tamamından kurtulduktan sonra bütün duyumsal imgeleri, ardından bütün soyut düşünceleri, akıl yürütme süreçlerini, istemleri ve diğer belirli zihinsel içeriği bilinçten çıkardığını düşünelim; o zaman bilinçten geriye ne kalırdı?"67 Bu soruya eğer Hume cevap veriyor

62 Konuya ilişkin detaylı bilgi için bk. Deleuze, Ampirizm ve Öznellik.

63 Hume, A Treatise of Human Nature, s. 143 = Türkçe’si: İnsan Doğası Üzerine Bir İnceleme, s. 174.

64 Hume, İnsan Doğası Üzerine Bir İnceleme, s. 174.

65 Deleuze, Ampirizm ve Öznellik, s. 8.

66 Stace, Mistisizm ve Felsefe, s. 86, 87.

67 Stace, Mistisizm ve Felsefe, s. 85, 86. 
olsaydı, o geriye bir şey kalmayacağını ya da ortaya çıkanın bilinçsizlik durumu olacağını söylerdi. Ancak Stace, bu noktada ondan ayrılır:

Kalan şey zihinsel bir içerik değil tam bir içsizlik, vakum ve boşluk olurdu. O zaman bilincin tamamen kaybolduğuna ve kişinin uykuya dald1ğına veya bilinçsiz olduğuna a priori olarak inanılacaktır. Fakat içe dönük mistikler -dünyanın her yerinden binlercesi- hep birlikte, bu belirli içerikten tamamen boşalma noktasına vardıklarını ancak o zaman olan şeyin bilinç dışına kayıştan bambaşka bir şey olduğunu öne sürerler. Tersine meydana gelen şey bir saf bilinç (pure consciousness) durumudur deneysel bir içeriğin bilinci olmaması anlamında saf. Onun kendi dışında hiçbir içeriği yoktur. ${ }^{68}$

Stace’in verdiği cevap, ilk bakışta İbn Sînânın nefsin varlığını kanıtlamak için verdiği "boşlukta uçan adam" örneğini akla getirir. ${ }^{69}$ Tipkı onun gibi Stace de, duyumla ilişkisi kesilen ve algılardan tamamen bağımsızlaştırılan bir bilinç durumunun, bilinçsizlik veya bilinç dışına kayma hali olmadığını öne sürer. Başka bir deyişle duyumsal algılayış sekteye uğradığında da bilinçlilik hali devam eder ve Stace bu bilinç durumuna "saf bilinç" adını verir. Dahası mistiklerin tecrübelerini de bu bilinç durumuna örnek gösterir. Böylece Stace ilk olarak benliğin tecrübenin ötesine uzanan tözel varlığını kabul eder. Peki mistiklerin tecrübe ettiği ve algılardan bağımsız olduğu öne sürülen saf bilinç nedir?

Doğrusu Stace saf bilinç hakkında detaylı açıklama yapmaktan sakınır. Yine de konuyu merak edenler için satır aralarında ortaya çıkan şu iki atıf, takip edilecek yolu gösterir. Bir yerde "saf" ile kastettiğinin, aşağ 1 yukarı Kant ` $ı$ kullandığı gibi, "herhangi bir tecrübi içerikten yoksunluk"70 olduğunu, başka bir yerde ise "Hume’un yadsıdığı ve mistiklerin onayladığ Kant’ın ileri sürdüğ̈ "tam algının aşkınsal birliği” (the transcendental unity of apperception) olduğunu söyler. ${ }^{71}$ Bu iki referans Stace'in, Kant'i takip ettiği izlenimini uyandırır. Bu noktada, bahsi geçen izlenimi değerlendirmek için atıfların işaret ettiği düşünceye kısaca değinelim.

Hatırlanacağı üzere Kant, Hume’un dikkat çektiği yoldan ilerleyerek Saf Aklın Kritiğinde tecrübeyi olanaklı kılan apriori bilginin araştırmasını yapar. Amacı ise tecrübenin sınırlarını açığa çıkarıp, bilginin alanını belirlemektir.

68 Stace, Mistisizm ve Felsefe, s. 85, 86.

69 İbn Sînâ, İşaretler ve Tenbihler, s. 107, 108.

70 Stace, "Mistiklerin Öğretileri", s. 127.

71 Stace, Mysticism and Philosophy, s. 89. 
Ancak Kant, Hume'dan farklı olarak duyusal tecrübenin, "Benim tecrübem" haline gelebilmesi için tecrübenin unsurlarından farklı, mantıksal olarak onları önceleyen bir "saf ben"in olması gerektiğini düşünür. ${ }^{72}$ Çünkü "ben" bilinci yalnızca iç algıdan kaynaklansaydı, Hume’un da dediği gibi, tecrübenin şartlarına tâbi olur, sürekli değişirdi. Filozof böyle olması durumunda, tecrübenin bütününün tek bir bilinçte birleşmeyeceğini ve dolayısıyla "benim tecrübem" denebilecek bir tecrübenin de olanaklı olmayacağını düşünür. ${ }^{73}$ Kant bu noktada, bütün tecrübeyi önceleyen ve onu olanaklı kılan aşkınsal bir zeminin gerektiğini öne sürer. Hume'dan farklı olarak tecrübenin temeline, tecrübenin unsurlarını önceleyen aşkınsal bir fiil yerleştirir: Aşkınsal özne $=\mathrm{x}$ olarak adlandırdığ 1 kendinde şeyden kaynaklanan ve algılayanın kendini idrak etmesine olanak sağlayan bu ilk transandantal düşünme fiili apperzeption yani "saf tam algı"dır. ${ }^{74}$ Saf tam algı, "ben" bilincinin aşkınsal birliğidir. ${ }^{75} \mathrm{Bu}$ fiil tecrübenin içeriklerini mantıksal olarak önceleyen apriori saf bir birliktir. Uzay ve zamanın bir birlik içinde kavranmasını ve tecrübenin bir bütünlük içerisinde "saf ben"e ait olmasını sağlar. ${ }^{76}$ Böylece tasarımlar tek bir bilinçte birleşir ve tek "ben"e ait olurlar. ${ }^{77}$ Başka bir deyişle, birbirinden farklı tecrübelerin her birinin aynı bilinçte ve birbiriyle ilişkili ve uyumlu olarak bileşmesi için, her tecrübeye potansiyel olarak eşlik eden bir kendini algılama bilinci olması gerekir. Eğer tecrübelerden bağımsız olarak algılayan kendini idrak etmeseydi, hiçbir bilgi ve bilgiler arasında hiçbir ilişki olanaklı olmazd. ${ }^{78}$ İște Kant’ın sisteminde bahsi geçen "tam algının aşkınsal birliği”, "ben”i kuran, "ben”e birliğini veren bütünleştirici bir ilkedir. Algıya yönelenin algıya sahip olan olarak kendini algılaması ve bunun tecrübeyi öncelemesi, Kant’ın düşünce dizgesinin kaynağında yer alır. Dolayısıyla Kant, Hume'dan ayrılarak "ben” in tözel varlığını kabul ettiği gibi, bunu alışılagelenden çok daha farklı bir biçimde açılar.

Yukarıdaki kısa hatırlatmadan sonra Stace'e geri dönüldüğünde, o Kant’a saf bilinci açılamak için atıfta bulunmuştu. Bu bağlamda bahsi geçen referans şu şekilde okunabilir. Stace şöyle demekteydi: "Hume’un yadsıdığ ve mistiklerin onayladığı "ben”, Kant’ın ileri sürdüğü "tam algının aşkınsal birliğidir”

72 Kant, Critique of Pure Reason, s. 247 (B 133-34).

73 Kant, Critique of Pure Reason, s. 247 (B 133-34).

74 Kant, Critique of Pure Reason, s. 246 (B 132); Gözkan, "Kant'in Metafizik ve Akıl Eleştirisi Üzerine Bir Eleştiri”, s. 25, 26; Çitil, Matematik ve Metafizik, s. 40.

75 Kant, Critique of Pure Reason, s. 246 (B 132).

76 Çitil, Matematik ve Metafizik, s. 40.

77 Kant, Critique of Pure Reason, s. 247 (B 133-34).

78 Kant, Critique of Pure Reason, s. 232 (A107). 
(the transcendental unity of apperception). ${ }^{79}$ Bunun anlamı Stace'in bahsettiği saf bilinç, öznenin tecrübe eden olarak kendini algılaması bilincine karşılık gelir. Tecrübenin içeriklerini mantıksal olarak önceler, saf ve aprioridir. Stace’e göre, işte mistikler tecrübenin şartlarına tâbi olan ve algının değişmesiyle değişen ampirik "ben"i değil, tecrübeyi olanaklı kılan saf bilinci tecrübe eder. ${ }^{80}$ Böylece onun saf bilinçle ne kastettiği biraz daha belirginlik kazanır.

Ancak şu noktaya dikkat etmek gerekir. Her ne kadar Stace, Kant'çı bir özne tasarımı kabul ediyor gibi görünse de, onun düşünce örgüsüne yakından bakıldığında aslında Kant’n çizdiği sınırları aşma iddiasında olduğu ortaya çıar. O, saf bilinç konusunda iki noktada Kant'tan ayrılır. Stace'in, Kant'tan ayrıldığı, daha doğrusu, Kant’ın çizdiği sınırların radikal bir şekilde dışına çıktığı ilk husus, saf bilincin tecrübesini kabul etmesidir. Onun dile getirimiyle, "Mistiğin ampirik benlikten kurtulmasının ardından normalde gizli olan saf benin ışığa çıktığı söylenebilir. Ampirik ben, bilinç akımıdır. Saf ben çoklu akımı bir arada tutan birliktir". "Ben, nesneleri kavramakla oyalanmadığı zaman kendinin farkına varır. Benin kendisi meydana çıkar." ${ }^{82}$ Oysa Kant'a göre, tecrübenin zeminini tutan ve mantıksal olarak tecrübenin unsurlarını önceleyen ve tecrübeye birlik verme işlevi gören "saf ben" in veya ona kaynaklık eden tam algının kendisi ne bir görüdür ve ne de bir kavramdır; bu bilinç, içi boş bir "düşünce" yahut "yalın bir temsil"dir. ${ }^{83}$ Anlama yetisi, bu temsili var saymaktan öteye gidemez. ${ }^{84}$ Yani temsilin kendisi görüde temsil edilemez ve bu sebeple de ne tecrübesi ne de bilgisi mümkün değildir. ${ }^{85}$ Dolayısıyla söz konusu ilke, tecrübeyi kurmada rol oynayan bununla birlikte tecrübeye konu olmayan temel unsurdur. ${ }^{86}$ Zaten Kant'in sözünü ettiği doğal dünyanın mukimi olan öznenin tecrübesi, her zaman fenomenal duyu deneyimine zorunlu olarak bağlıdır. Aklını yanlış kullanmadıkça bu sınırları aşamaz. Kant, "ruh-görücülere" karşı yazdığı eserinde bu türde

79 Stace, Mysticism and Philosophy, s. 87.

8o Stace, Mysticism and Philosophy, s. 89.

81 Stace, Mistisizm ve Felsefe, s. 86 (A. Tüzer'in tercümesinden yararlanmakla birlikte "empirical ego" kelimesini "deneysel ego" yerine "ampirik ben" şeklinde ve "pure ego" kelimesini "salt ego" yerine "saf ben" olarak tercüme etmeyi tercih ettik (Bk. Stace, Mysticism and Philosophy, s. 87).

82 Stace, Mistisizm ve Felsefe, s. 86 (Vurgu eklenmiştir).

83 Kant, Critique of Pure Reason, s. 432 (A382).

84 Altuğ, "Önyazı: Yargı ve Bilinç", s. 22.

85 Gözkan, "Kant'ın Metafizik ve Akıl Eleştirisi Üzerine Bir Eleştiri”, s. 14. Ayrıca konuya ilişkin bk. Sahabettin Yalçın, "Kant'ta Transandantal Ben Bilinci", s. 39-71.

86 Kant, Critique of Pure Reason, s. 232 (A 107), 233 (A 109), 414 (B 404), 457 (B 430); Agamben, Çocukluk ve Tarih, s. 38. 
irrasyonel sapmaları yanılsama olarak nitelendirir. ${ }^{87}$ Dolayısıyla Stace'in, "Bu ayrımlaşmamış birlik içe dönük mistik tecrübenin özüdür"88 düşüncesinin, Kant'ın dizgesinde mâkul bir karşıllğg yoktur.

Stace'in Kant'tan ayrıldığı ikinci nokta, tecrübenin konusu ile ilgilidir. Stace, ampirik veya fenomenal "ben"i bireyselliğin ilkesi kabul eder. Saf bilinci ise bireylerden ve zamandan bağımsız mutlak evrensel bilinçle özdeşleştirir. Stace, bireyselliğin ilkesini sorguladığı bölümde şöyle der: "A ve B (bireyleri) bütün deneysel içeriği kendi içlerinde yok ederlerse o zaman ortada onları birbirinden ayıran ve iki ayrı varlık kılan hiçbir şey kalmaz." ${ }^{89}$ Bununla birlikte aynı zamanda şunu da kabul eder:

Mutlak benliğin birliği olan Birlik'in herhangi bir bireysel benlikten bağımsız olduğu açıklığa kavuşturuldu. Çünkü o bütün bireylerin üzerinde kemer oluşturur, böylece bireylerin yaşadıkları zamanların üzerinde kemer oluşturur. $\mathrm{O}$ yalnızca içinde bulunduğumuz yılda bir arada yaşayan 'sen' ve 'ben’in saf ben'i değil, aynı zamanda tüm geçmiş ve geleceğin bilinçli varlıklarının saf ben'idir. ..... yani o özne ötesidir. ${ }^{90}$

Yukarıdaki açıklamalarla birlikte, Stace'in mistik tecrübeyi, dinî, sezgisel veya his tecrübesi olmaktan çıkararak konusu "evrensel ben" olan bir tür entelektüel tecrübe olarak yorumladığı ortaya çıkar. Zira bir bireyi diğerinden ayıran, farklı kılan zihinsel-entelektüel bilinci iken, bunun ötesindeki saf bilinç her bireyde aynı ve bu da evrensel olanla özdeştir. ${ }^{91}$ Bu ifadelerinden doktorasını Hegel üzerine yapmış olan Stace'in, Kantçı değil de Hegelci "aşkınsal bir özne" tasarımından etkilendiği ya da ona daha yakın olduğu anlaşılır. Çünkü Agamben’in de işaret ettiği gibi, Kant sonrası Alman idealizminin projesi "aşkınsal özne ile ampirik bilinci tek bir mutlak öznede tekrar" birleştirmektir. ${ }^{92} \mathrm{Bu}$ düşünce geleneğinde "mutlak ben, mutlak özdeşlik, kendinde ide" gibi kavramlarla ifade edilen Kant’ın ısrarla bilinemeyeceğini söylediği "aşkınsal özne", tek tek kişilerin aklını aşan ve bilinmesi olanaklı olan "mutlak akıl"a karşılık gelir. ${ }^{93}$ Stace de benzer biçimde mistik tecrübe-

87 Kant, Dreams of Spirit-Seer.

88 Stace, Mistisizm ve Felsefe, s. 86.

89 Stace, Mistisizm ve Felsefe, s. 153.

90 Stace, Mistisizm ve Felsefe, s. 199. A. Tüzer'in tercümesinden yararlanmakla birlikte "pure ego" kelimesini "salt ego" yerine "saf ben" olarak tercüme etmeyi tercih ettik (Bk. Mysticism and Philosophy, s. 196, 197).

91 Wainwright, "Stace and Mysticism", s. 145.

92 Agamben, Çocukluk ve Tarih, s. 39.

93 Orman, “Alman İdealizmi ve Hegel”, s. 56. 
yi aslında özneler ötesi "mutlak"ın tecrübesi olarak yorumlar. Bunu açıkça dile getirdiği cümlesi şöyledir: "İçe dönük mistik, duyumlardan, imgelerden ve düşünce içeriğinden kurtularak sonunda kendi içinde Evrensel Ben veya Tanrı ile birleșen ya da bir olan saf beni bulur." Bu "... bireyselliğin, "sınırsız varlığın" içinde "eriyip yok olma" veya "solup kaybolması" tecrübesidir." ${ }^{4}$ Böylece mutlak özne, "Bilincin sadece biçimi ya da aracı ya da sınırı olmaktan çıkar ve yeni mutlak öznenin asıl özüne dönüşür."95 "Zihin 'kendisi d1şındaki bütün olası içerikten kurtulur.' Tüm deneysel içerikten sıyrılma bu tecrübenin ana niteliğidir. $\mathrm{O}$ zaman geriye ne kalır? Benin varlığını yadsıyan Hume’un pasajından anlaşıldığı kadarıyla bilinç dışı değil elbette. Geriye kalan saf bendir." ${ }^{96}$ Bu sebepledir ki Stace, mistik tecrübenin Tanrı ya da dinî bir varlık ile ilişkilendirilmesini yalnızca kişisel bir yorum olarak görür ve tecrübenin kendisinde buna yer olmadığında ısrar eder. Çünkü dünyanın her yerinden mistikler, dinlerin kabul ettiği bir Tanrı ile değil, özneler ötesi olan "mutlak" ile birleşir.

Aslında Stace'in bu kısımda yer verilen düşünceleri, daha önceki teolojik açılamalar ve mistik geleneklerdeki dinî yorumlamalarla karşılaştırıldığında oldukça felsefî kalır. O, özneler ötesi "evrensel ben" ile birleşmenin olanağını kabul ederek, hem Kant'ın çizdiği sınırların dışına çıkar, hem de anlaşılamaz ya da saçma olduğu gerekçesiyle çoğu defa felsefeye konu edilmeyen ya da teolojik tartışmalarda dinin sınırları içerisinde yer alan mistisizmi derin felsefî konularla ilişkilendirir. Konuya felsefedeki tartışmalar ışığında bakıldığında mistisizm ilgi çekici hale gelir. Ancak maalesef Stace konuyla ilgili daha fazla açıklamada bulunmaz. Bunun yerine mistik tecrübe anlatıları arasındaki benzerliklere dikkat çekerek, mistisizmle ilgili sorunları cevaplamayı tercih eder. Her ne kadar Stace'in bilinçle ilgili açıklamaları konuyu tam anlamada yetersiz olsa da, düşüncesinin temel çerçevesi ve referans aralığ gün yüzüne çıkmıştır.

\section{Değerlendirme}

Buraya kadar Stace'in mistik tecrübe, mistik tecrübenin türleri, tecrübeyle din arasındaki ilişki, tecrübe sonrası yorum süreci, tecrübeler arasındaki yorumdan kaynaklanan farklılıklar gibi mistisizmle ilgili temel düşünceleri

94 Stace, Mistisizm ve Felsefe, s. 222.

95 Agamben, Çocukluk ve Tarih, s. 39.

96 Stace, Mistisizm ve Felsefe, s. 110. A. Tüzer'in tercümesinden yararlanmakla birlikte "pure ego" kelimesini "salt ego" yerine "saf ben" olarak tercüme etmeyi tercih ettik (Bk. Stace, Mysticism and Philosophy, s. 108). 
belirginlik kazand. ${ }^{97}$ Bununla birlikte, söz konusu düşüncelerin temelinde yer alan saf bilinç ve bu bilincin felsefî zeminine de değinildi. Makalenin son kısmında Stace’in açıklama modeli, şu üç iddia çerçevesinde değerlendirilecektir: 1. Stace'in mistisizmin felsefî okuması, kendisinin iddia ettiği gibi fenomenolojik değildir. 2. Mistik tecrübenin saf bilinç tecrübesi olduğu iddiası, bilinçle ilgili felsefî bir varsayıma dayanır. Bu varsayım "ben"in aşkınsal temelinin tecrübe edilebilir olduğudur. 3 . Stace’ in düşüncelerinin temelinde yer alan bu varsayım yeterince temellendirilmemiştir. Bu sebeple de Stace'in açıklama modeli yeterince temellendirilmemiş bir argümandan hareketle gerçekleştiği için problemli ve zayıftır.

Makalenin birinci bölümünden hatırlanacağı üzere, Stace kendi çalışmasının o ana kadar yapılmış araştırmalardan farkını takip ettiği yönteme bağlıyordu. Kendi ifadesiyle amacı, mistik tecrübe "tasvirlerini inceleyerek, eğer varsa, tümevarımsal olarak ortak ana niteliklerine varmaya" çalışmaktır. ${ }^{98}$ Bunun için Stace, "Önce gözlemsel (empirically) olarak ne tip ve ne tür deneyimlere mistik dendiğini saptamak, bunların ana özelliklerini belirlemek ve sınıflamak, sınıfa ait sınırları belli etmek ve ilgisiz tipleri dışta bırakmak için alanı araştırmamız gerekiyor" der. ${ }^{99}$ Bundan sonra "seçilen ve tanımlanan bu tecrübelerin ya da zihin hallerinin" felsefî sorulara "işık tutup tutmadığına” bakacağını söyler. ${ }^{100}$ Pek çok filozof ve düşünürün dikkat çektiği üzere, dünyanın farklı yerlerinden pek çok kimse saf bir tecrübe yaşadığını iddia eder. Hem sayılarının fazlalığı hem de iddialarındaki bazı ortak özellikler gerçekten de bu konuyu ilgi çekici hale getirir. Ancak ilk olarak şunu sormak gerekir: Yalnızca mistik tecrübe anlatılarına dayanarak tecrübenin doğası hakkında konuşulabilir, saf bilincin tecrübe edildiği iddiasına ulaşılabilir mi? Böyle bir geçiş yapılabilir mi? Söz konusu olgu fenomenolojik olarak incelendiğinde, Stace'in ulaşttğı sonuçlar anlamlı mıdır?

Doğrusu dikkatli bir okuma ile yukarıdaki soruların cevabı doğrudan Stace'ten alınabilir. Onun çoğu defa dikkatten kaçan ifadeleri şöyledir: "Yalnızca mistiklerin uzlaşmasının kendi başına kanıtlayabileceği tek şey onların deneyimledikleri şeyi yanlış betimlemediklerini göstermesinin

97 Şüphesiz Stace’in düşüncelerini daha detaylı ele almak mümkündür. Ancak burada, makalenin sınırları düşünülerek konunun amacına uygun biçimde önemli noktalarına değinilmiştir (konuya ilişkin yapılmış son çalışmalardan biri için bk. Fatma Yüce, "Dini ve Mistik Tecrübede Evrensel Öz Problemi: Walter Stace - Steven Katz Karşılaştırması", [doktora tezi], İstanbul Üniversitesi Sosyal Bilimler Enstitüsü, 2015).

98 Stace, Mistisizm ve Felsefe, s. 43.

99 Stace, Mistisizm ve Felsefe, s. 7.

100 Stace, Mistisizm ve Felsefe, s.7. 
dışında- insanoğlunun yaratılışındaki, onların benzer deneyimleri yaşamalarına neden olan evrensel bir öğenin varlığıdır." ${ }^{101}$ Devamında gelen cümle daha dikkat çekicidir: “... Bütün insanlar mistik deneyime sahip olsa bile ve bütün bu deneyimler tıpatıp birbirinin aynı olsa bile tek başına bu, insanoğlunun doğasında onlara bu benzer deneyimleri yaşatan gerek fiziksel gerekse zihinsel bir şeyin var olduğu gerçeğinden daha fazlasını gösteremez." ${ }^{102} \mathrm{Bu}-$ nun anlamı eğer mistik tecrübe olağan tecrübe ile benzer koşullara sahip olsa yani herkeste ortak olsa, bu durum insanın bu türde tecrübe yaşamasına olanak veren bir şeyin olduğundan "öte" bir şeye işaret etmez. Yani aslında Stace'in kendisi de tecrübelerin yaşanmış olmasının, farklı geleneklerde yaşandığ dadır. Diğer bir ifadesi de şöyledir: “... Bu son derece anlamlı düşünce birliği, deneyimlerin yanlış aktarılmadığını, tersine gerçekten tam olarak mistiğin gerçekleştiğini söylediği şey olduğu yönünde çok güçlü bir kanıta varır."103 Dolayısıyla mistik tecrübenin fenomenolojik incelemesiyle ancak şu iki sonuca ulaşılabilir: 1. Mistik tecrübe yaşadığını söyleyen kişiler, böyle bir tecrübe yaşadıkları konusunda yanılmamaktadırlar. 2. İnsanda bu türde benzer bir tecrübenin yaşanmasına sebep olan fiziksel ve zihinsel bir şey olabilir. Bu sonuçlarla ortaya çlkan, Stace'in, mistik tecrübeye dair anlatılar arasındaki benzerliğe rağmen, yalnızca bu anlatılar üzerinden bu iki sonuçtan daha fazlasına ulaşılamayacağını açıkça kabul ettiğidir. Dolayısıyla mistik tecrübeye ilişkin olgular ve önermeler doğru da olsa, tecrübenin kendisinden tecrübenin mahiyetine ilişkin bir teoriye geçebilmek için başka delillerin gerekli olduğu da ortaya çıkar. Bunun anlamı, bu dizgede mistisizmin felsefî okuması yalnızca fenomenin kendisine dayanmaz ve bu sebeple de fenomenolojik değildir.

Gelinen bu noktada akla başka bir soru takılır: Eğer mistik tecrübenin yaşanmış olmasından yukarıdaki iki sonuç dışında bir şeye ulaşılamazsa, acaba Stace mistik tecrübenin saf bilinç tecrübesi olduğu, saf bilinç tecrübesinin "evrensel ben" ile birliğe karşllık geldiği, içe dönük mistik tecrübenin ortak öze sahip olduğu vb. iddialara nasıl ve hangi delillerle ulaşır? Aslında bu sorunun cevabını da Stace'de bulmak mümkündür. Ona göre, kendi argümanı ancak bilinçle ilgili bir öncülü kabul etmesi halinde geçerli olur. Onun ifadesiyle, "Bildiğim kadarıyla hiçbir mistiğin veya başka bir kimsenin şimdiye kadar üzerinde durmadığı, hatta ayırdında bile olmadığı, ancak öncüllerini kabul ettiğimiz takdirde mistiğin görüşünü kuşkucununkine karşı kesin olarak

101 Stace, Mistisizm ve Felsefe, s. 139, 140 (Vurgu eklenmiștir). 102 Stace, Mistisizm ve Felsefe, s. 139, 140 (Vurgu eklenmiştir). 103 Stace, Mistisizm ve Felsefe, s. 139, 140. 
destekleyen bir akıl yürütme zinciri vardır."104 Yani yalnızca mistik tecrübe anlatılarına bağlı kalınırsa, mistisizmi kuşkucuya karşı savunmak olanaklı değildir. Mistisizm hakkında felsefî bir düşünce üretebilmek için Stace, birtakım öncüllerin kabulünü zaruri görür. Onun sözünü ettiği bu öncül "Mistiğin gerçekte bilincine ait bütün deneysel içeriği yok ettiği ve kendi saf ben’i olan saf bilinçle baş başa kaldığı” dır. ${ }^{105}$ Ardından Stace devam eder: Bu öncül “... bir kez bu kabul edilince, bu noktada durmanın mantıksal açıdan olanaksız olduğu ve saf bireysel ben'in gerçekte yalnızca bireysel ben olmayıp evrensel ve kozmik olduğunu da varsaymak zorunda olduğumuzu görürüz."106

Böylece sorun açıklığa kavuşur. Stace mistik tecrübe anlatılarından hareketle insanda mistik tecrübe yaşanmasına sebep olan "fiziksel ve zihinsel bir şey"in ${ }^{107}$ olduğu sonucunda kalmaz ve bunun ne olduğuna dair fikir yürütür. ${ }^{108}$ Yani çalışmasına kendisinin kabul ettiği bir öncülle devam eder. Bu bakımdan onun argümanı ve yaptığı açıklamalar aslında apriori bir varsayımı içerir. Bu varsayım "saf 'ben'in tecrübesinin olanağı"dır. Dolayısıyla aslında bu dizgede mistisizm, belirli bir öncül doğrultusunda yorumlanır. Dahası Stace'in sözünü ettiği bu öncül, felsefenin en karmaşı problemlerinin temelinde bulunan ve felsefî tutumu doğrudan etkileyen bir öncüldür. $\mathrm{Bu}$ noktada çalışmanın ikinci bölümünü hatırlamak gerekir. Stace, Hume sonrası felsefecilerin yaygın olarak reddettikleri aşkınsal "ben"i, Kant’a yaptığı atıfla kabul ediyordu. Dahası saf bilincin tecrübe edilebileceğini ve saf bilinç tecrübesinde bireysel farklılıkların aşıldığı aynı "evrensel ben" ile birlik yaşandığını öne sürmekle Kant'ı aşarak idealizme yaklaşmaktaydı. İşte söz konusu bu felsefî kabulünü düşüncesinin temeline yerleştirir ve sonrasında mistik tecrübe anlatılarını buna göre değerlendirir. Bu bağlamda Stace'in argümanı esasında şöyledir:

1. Bilincin duyumlardan bağımsız ve onları aşan bir üst formu, aşkınsal ben, saf bilinç vardır.

2. "Aşkınsal ben” veya saf bilinç, evrensel bilinç ile özdeştir.

3. Saf bilincin tecrübesi evrensel bilinç ile birleşme tecrübesidir.

-Mistik tecrübe evrensel bilinç ile birleşme tecrübesidir.

\footnotetext{
104 Stace, Mistisizm ve Felsefe, s. 151, 152 (vurgu eklenmiştir).

105 Stace, Mistisizm ve Felsefe, s. 151, 152.

106 Stace, Mistisizm ve Felsefe, s. 151, 152.

107 Stace, Mistisizm ve Felsefe, s. 139, 140.

108 Stace, her ne kadar mistik tecrübeye sebep olan "fiziksel veya zihinsel bir şey" ifadesini kullansa da, ileride görüleceği gibi kendisi tamamen zihinsel bir sebebi kabul etmektedir.
} 
Görüldüğü üzere, Stace’in mistik tecrübeyle ilgili düşüncesi, felsefî bir kabulün sonucudur. Başka bir deyişle, önce bir argüman oluşturulur ve ardından mistik tecrübe bu argümana ampirik destek sağlama görevi görür. ${ }^{109}$ Dolayısıyla Stace çalışmasında aslında mistisizmin fenomenolojik soruşturmasını yapmaz. Mistisizmle ilgili sorulara verilen bütün cevaplar aslında yukarıdaki felsefî tavırdan kaynaklanır. Meselâ mistik tecrübenin "mutlak" ile birlik tecrübesi olması, içe dönük mistik tecrübe ile dışa dönük mistik tecrübe sınıflaması saf bilinçle ilgili kabulün sonucudur. Yine içe dönük mistik tecrübelerin ortak öze sahip olduğu iddiası bu kabule bağlıdır. Çünkü bağlamlar üstü bir ortaklıktan bahsedebilmek için buna olanak sağlayan bir "yeti" olması gerekir ki bu açılama modelinde benliğin tözel varlığı bu görevi görür. Aynı şekilde mistik tecrübe ve yorum arasında yapılan ayırım, başka bir ifadeyle mistiklerin tecrübelerini “Tanrı, brahman, hiçlik, fenâ, sunyata" gibi farklı şekillerde adlandırmalarının sadece bir yorum farkı olduğu iddiasının temelinde aynı felsefî teori vardır. Yani Stace'in zihinsel-entelektüel bilinç ile saf bilinç arasında yaptığı ayırım, hem mistiğin çabasını anlamlı hale getirir hem de ona mistiklerin "hiçlik, birlik, yokluk, fenâ, nirvana" gibi anlaşılması güç ifadelerini anlama olanağı sağlar.

Mevcut durumda şu hususa dikkat edilmelidir. Stace ilk olarak mistik tecrübenin fenomenolojik bir tahlilini yapıp, ardından konunun felsefî sorunlarla ilişkisini ve varsa bu sorunlara verdiği yanıtları inceleyeceğini söyler. Oysa açığa çıktığı gibi kendisi fenomenin mantıksal olarak gerektirmediği sonuçlara ulaşmıştır. Yani mistiklerin ifadelerinde gerçekten de tecrübenin benzer olabileceğini düşündürten bazı ifadeler vardır. Bunu inkâr etmek mümkün değildir. Ancak bu benzerliklerin saf bir tecrübeye dayandığını iddia etmek için mantıksal bir sebep yoktur. Bahsi geçen varsayım, olguyu açıklamadaki diğer bütün ihtimallere aynı uzaklıktadır. Zaten yakından bakıldığında esasında Stace'in fenomenolojik veya tümevarımsal bir yöntem takip etmeyip, tümdengelimsel bir yöntem kullandığı, teorik kabullerine göre mistik tecrübeyi ele alıp birtakım sonuçlara ulaştığı ve dahası bunun da farkında olduğu ortaya çıkar. Stace yalnızca mistik tecrübe anlatılarını dikkate alsaydı, kendisinin de ifade ettiği gibi, bu türden felsefî sonuçlara ulaşamazd. ${ }^{110}$ Yani Stace'in kabul ettiği öncüller doğru kabul edilse bile, bu, ulaştığı sonucu zorunlu kılmaz. Dolayısıyla Stace'in çıkarımı sorunludur. Peki acaba o niçin açıç̧a felsefî bir yorum yaptığını söylemek yerine çalışmasını fenomenolojik bir tahlil olarak sunmakta ve konunun işleyişini bu şekilde devam ettirmekte ısrar etmiştir? Maalesef bu soru cevapsız kalır.

109 Shear, “On Mystical Experiences as Support”, s. 320.

110 Stace, Mistisizm ve Felsefe, s. 139, 140. 
Bunlarla birlikte, Stace'in argümanı için neler söylenebilir? Stace'in mistik tecrübeyi bireysellik, bilinç, aşkınsal bilinç gibi felsefî konularla ilişkilendirmesi oldukça önemlidir. Zaten mistisizmin XIX. yüzyllda ilgi görmesi, dönemin felsefî paradigmasının sınırlandırmalarını kıracak bir arayışla ilgilidir. XVIII. yüzyıldan itibaren teologlar ve felsefeciler kimi zaman Tanrı́nın varlığını veya bilgisini delillendirmek, kimi zaman dolaysız bir tecrübenin imkânını öne sürmek, kimi zaman da evrensellikle ilgili problemlere cevap vermek için mistik tecrübeye başvurmuşlardır. Ancak Stace'in dikkatini çeken nokta önemlidir. Mistisizmle ilgili bir tartışma, Hume’un daha önce bahsi geçen bireysel töz meselesiyle yakından ilgilidir. Çünkü hangi dine veya kültüre mensup olursa olsun mistik, olağan tecrübenin sınırlarını aştığını öne sürer ki zaten uzun ve yorucu uygulamalarını da bu amaçla gerçekleştirir. Eğer mistik yanılmıyor veya yalan söylemiyorsa, insanın hangi yetisinin bu türde bir tecrübe yaşamasına olanak sağladığı, mistiklerin tecrübeye ulaşmak için kullandıkları yöntemler ile tecrübeleri arasında nasıl bir ilişki olduğu merak konusudur. Dolayısıyla Stace konuyu saf bilinç üzerinden ele alarak önemli bir noktaya dikkat çekmiştir. Ancak maalesef çalışmanın ikinci bölümünde görüldügü üzere $o$, saf bilinçle ne kastettiğini yeterince açıklamaz. Hatta Kant’a yaptığı referanslar bile net değildir. Dahası onun kabul ettiği şekli ile mistik tecrübenin Kant’in felsefesinde yeri yoktur. Hatırlanacağ üzere, Kant Saf Aklın Kritiğìnde idealizmin "ben" kavramını eleştirirken -tabii filozofun dışarıda bırakmak istediği isim Platon'dur- benin duyusal alan dışında noetanın veya başka bir deyişle kendinde şeyin dolaysız görüsüne sahip olmasına olanak sağlayacak entelektüel bir yetiye sahip olmadığının altını çizmekteydi. ${ }^{111}$ Oysa Stace, Kant üzerinden entelektüel bir tecrübeye işaret eder. Dolayısıyla aslında Stace mistisizmle ilgili açıklamaları doğrudan Kant’ın çizdiği tecrübenin sınırlarının dışındadır. Bu bakımdan da Stace'in Kant ile hesaplaşması ve kendi iddialarını temellendirmesi beklenir. Fakat o argümanının temellerini açıklayıp, onları sağlamlaştırma ihtiyacı duymaz. Hangi noktalarda Kant'ı kabul edip, nerede ondan ayrıldığını, bunun nasıl gerçekleştirdiğini açıklamaz. Sadece kullandığ ifadelerden idealizme yaklaştığ 1 izlenimini verir ki bu herhangi bir referans içermeyen bir izlenimden öte değildir. Bütün bu muğlaklığa rağmen mistisizmi tamamen bu düşünce üzerinden ele alır. Mistik tecrübe, saf bilinci destekleyen bir olgu olarak sunulur. $\mathrm{Bu}$ şartlar altında, Stace'ten beklenen muğlak kalan noktaları açıklaması ve okuyucuya mâkul gerekçeler sunmasıdır. Ancak maalesef satır arası atıflar ve bazı değinilerden daha fazlasına ulaşılamaz.

111 Kant, Critique of Pure Reason, s. 248 (B 135). 
Gelinen bu noktada önemine binaen birkaç noktanın altını tekrar çizmek gerekir. Öncelikle Stace'in açıklama modeli ele alınırken, onun tümevarımsal ve fenomenolojik bir yöntem takip etmediğine dikkat edilmelidir. Yani saf bilinç, içe dönük mistik tecrübe, ortak öz gibi düşünceler yalnızca mistik metinlerle sınırlı kalınarak ulaşılmış değildir. İkincisi ortaya çıktığı üzere Stace'in argümanı, tecrübeyi olanaklı kılan aşkınsal temelin yani saf "ben"in tecrübesinin imkânına dayanır. Daha önce de değinildiği gibi özellikle Kant sonrası süreçte Kant'ı dikkate alarak saf "ben" in tecrübesini iddia etmek, Kantçı tecrübe anlayışından uzaklaşmayı gerektirir. Bunun için de ya yeni bir tecrübe tanımı ortaya konmalı ya da mevcut Kantçı olmayan ve saf "ben"in tecrübesine olanak sağlayan bir tecrübe anlayışı kabul edilmelidir. Oysa Stace, çalışmasında saf bilinçle ilgili yalnızca Kant’a referansta bulunur. Onun Alman idealizmine yakın olması, ifadelerinin yorumundan ibarettir. Başka bir deyişle Stace'in kendisi, çalışmasında Hegel veya herhangi bir başka Alman filozofunu anmaz. Dolayısıyla nasıl bir tecrübe anlayışına sahip olduğu bir türlü açılığa kavuşmaz. Durum böyle olunca argümanın temeli zayıf kalır. Konuyu tartışmak için yeterli bağlam oluşmaz. Dahası eğer kendisini Hegelci görüyorsa da Hegel'in düşünce sisteminden mistisizme nasıl kapı araladığını da açıklaması gerekirdi. Dikkat edilmesi gereken başka bir nokta Stace’in mistisizmi dinden tamamen bağımsız bir fenomen olarak görmesidir. Yani XIX ve XX. yüzyılın metafizik karşıtı söylemlerinin etkisinde kimi zaman Stace'in açılamaları teolojik bir mistisizm lehine gibi düşünülmüş olsa da, yakından bakıldığında yorumlama süreci dışında dini tamamen dışlayan bir modeldir. Stace'in düşüncesini kabul ederken, bunun ortaya ç1karacağı problemleri hesaba katmak gerekir.

Sonuç olarak, kabul etmek gerekir ki Stace, mistisizmin felsefede hangi türden sorunlarla ilişkili olduğunu göstermede ve tecrübenin dile aktarılmas1, tecrübeler arasındaki çeşitlilik, tecrübe ve din arasındaki ilişki gibi başa çıkılması güç sorunlara verdiği cevaplarda oldukça başarılıdır. Dahası geliştirdiği açıklama modeli mistik metinler arasındaki farklılıkları açıklama ve "ortaklıklar"ı öne çıkarma noktasında diğerlerine kıyasla daha ikna edici ve etkilidir. Stace'in dediği gibi "Mistiklerin mistik deneyimin evrensel olanaklılığına ilişkin bu iddiasının doğru olduğuna inanmak akla uygun” olabilir. Fakat sorun şudur ki felsefî bir incelemede beklenen, olası ihtimallerden birini öne çıarmak yerine öne sürülen iddiaların temellendirilmesidir. Stace'in açıklamaları derinlemesine incelendiğinde okuyucu mistisizme ilişkin çözümler bulmak yerine daha zor ve karmaşı sorunların önüne bırakılır. Oysaki bu türdeki kişisel deneyimleri bir teoriyle açıklamak için daha karmaşık süreçleri dikkate almak gerekir. Bu sorunlar da aslında güçlü gibi görünen 
açıklama modelinin gücünü zayıflatmakta ve ortaya konan pek çok açıklamanın geçerliliğine gölge düşürmektedir. Stace’in açıklama modeli tümdengelimsel olduğu için değil, argümanının temelleri muğlak, delilleri eksik ve açıklamaları yetersiz olduğu için zayıftır. Her ne kadar XX. yüzyıldaki James, Otto, Underhill, Zaehner gibi diğer araştırmacıların çalışmalarıyla birlikte Stace'in düşünceleri alanı canlandırmış ve konunun felsefî önemine dikkat çekmişse de, yakından bakıldığında, Stace’in argümanlarının tecrübenin kendisine dayanmadığı ve teorik olarak da yetersiz olduğunu ortaya çıkarır. Bu bakımdan mistisizme ilişkin sorunlar hâlâ canlıdır ve çözüm beklemektedir.

\section{Bibliyografya}

Agamben, Giorgio, Çocukluk ve Tarih: Deneyimin Yıkımı Üzerine Bir Deneme, çev. Betül Parlak, İstanbul: Kanat Kitap, 2010.

Akdemir, Betül, “Mistik Tecrübenin Özüyle İlgili Çağdaş Kuramlar Bağlamında Türkiye’de Mistik Tecrübe Çalışmaları”, I. Türkiye Lisansüstü Çalışmaları Kongresi: Bildiriler Kitabı, ed. Furkan Yıldız - Ümit Güneş, İstanbul: İlmî Etüdler Derneği (İLEM) - Konya: Konya Büyükşehir Belediyesi, 2013, s. 72-80.

Altuğ, Taylan, “Önyazı: Yargı ve Bilinç Kant’ın Özne Felsefesi Üzerine”, Gilles Deleuze, Kant’in Eleştirel Felsefesi içinde, çev. Taylan Altuğ, İstanbul: Panel Yayınları, 1995, s. 9-24. Ayer, Alfred Jules, Language Truth and Logic, London: Penguin Books, 1990.

Bouyer, Louis, "Mysticism: An Essay on the History of the Word", Understanding Mysticism, ed. Richard Woods, London: The Athlone Press, 1981, s. 42-55.

Çitil, Ahmet Ayhan, Matematik ve Metafizik, İstanbul: Alfa Yayınları, 2012.

Deleuze, Gilles, Ampirizm ve Öznellik: Hume Açısından İnsan Doğası Üzerine Bir Deneme, çev. Ece Erbay, İstanbul: Norgunk Yayıncılık, 2008.

Eckhart, Meister, Ben, Meister Eckhart, Tanrinın Kendisinden Hiçbir Şeyi Saklamadı̆̆ Adam, der. David O’Neal, çev. Aslı Özer, İstanbul: Klan Yayınları, 2003.

Eliade, Mircea, Yoga: Ölümsüzlük ve Özgürlük, çev. Ali Berktay, İstanbul: Kabalcı Yayınevi, 2013.

Forman, Robert K. C., "Introduction: Mysticism, Constructivism, and Forgetting", The Problem of Pure Consciousness Mysticisim and Philosophy, ed. Robert K. C. Forman, New York: Oxford University Press, 1990, s. 3-52.

Gimello, Robert, "Mysticism in Its Contexts", Mysticism and Religious Tradition, ed. S. T. Katz, New York: Oxford University Press, 1983, s. 61-88.

Gözkan, Bülent, "Kant’ın Metafizik ve Akıl Eleştirisi Üzerine Bir Eleştiri”, Yeditepe'de Felsefe, 1 (2002): 21-79.

Harmless, William, Reading Mystics: Text, Community, Experience, New York: Oxford University Press, 2008.

Hume, David, A Treatise of Human Nature, Oxford: Oxford University Press, 2001 = Türkçesi: İnsan Doğası Üzerine Bir İnceleme, çev. Ergün Baylan, İstanbul: BilgeSu Yayınları, 2009. 
İbn Sînâ, el-İ̧ârât ve't-tenbîhât: İşaretler ve Tenbihler, çev. Ali Durusoy v.dğr., İstanbul: Litera Yayınları, 2005.

James, William, The Varieties of Religious Experience: A Study in Human Nature, Oxford: Oxford University Press, 2012.

Jay, Martin, Deneyim Şarkıları: Evrensel Bir Tema Üzerine Modern Çeşitlemeler, çev. Barış Engin Aksoy, İstanbul: Metis Yayınları, 2012.

Kalın, Fetullah, Rudolf Otto’da Din, Kutsallk ve Mistik Tecrübe, İstanbul: Ötüken Neşriyat, 2014. Kant, Immanuel, Critique of Pure Reason, çev. Paul Guyer - Allen W. Vood, Cambridge: Cambridge Universty Press, 1998.

Kant, Immanuel, Dreams of Spirit-Seer, çev. Emanuel F. Goerwitz, New York: The Macmillian Co., 1900.

Orman, Enver, "Alman İdealizmi ve Hegel", Kant Sonrası Metafizik Üzerine Konuşmalar, ed. Erdal Yılmaz, İstanbul: Küre Yayınları, 2012.

Otto, Rudolf, The Idea of Holy: An Inquiry into the Non-Rational Factor in the Idea of the Divine and Its Relation to the Rational, çev. John W. Harvey, London: Penguin Books, 1959 = Türkçesi: Kutsal'a Dair: Kutsal Tasarısındaki Sezgisel Faktör ve Rasyonelle Olan İlişkisi Üzerine, çev. Sevil Ghaffari, İstanbul: Altıkırkbeş Basın Yayın, 2014.

Otto, Rudolf, Mysticism East and West, New York: The Macmillian Company, 1932.

Overall, Christine, "Mysticism, Phenomenalism, and W. T. Stace", Transactions of the Charles S. Peirce Society, 18/2 (1982): 177-90.

Russell, Bertnard, Din ile Bilim, çev. Akşit Göktürk, İstanbul: Elif Yayınları, 1963.

Shear, Jonathan, "On Mystical Experiences as Support fort the Prennial Philosophy”, Journal of the American Academy of Religion, 62/2 (1994): 319-42.

Staal, Frits, Exploring Mysticism, Middlesex: Penguin Books, 1975.

Stace, Walter T., Mysticism and Philosophy, London: Macmillian, $1960=$ Türkçesi: Mistisizm ve Felsefe, çev. Abdüllatif Tüzer, İstanbul: İnsan Yayıları, 2004.

Stace, Walter T., "Mistiklerin Öğretileri”, Bilimname, çev. Canan Kuvanc1, 10/1 (2006): 117-31.

Stace, Walter T., The Teachings of the Mystics, New York: Mentor Book, 1960.

Stace, Walter T., The Theory of Knowledge and Existence, Westport: Greenwood Press, 1970. Sunar, Cavit, Mistisizmin Ana Hatları, Ankara: Ankara Üniversitesi İlâhiyat Fakültesi Yayınları, 1966.

Sunar, Cavit, Mistisizm Nedir?, İstanbul: Kılıç Kitabevi, 1979.

Swinburne, R., The Existence of God, Oxford, Clarendon Press, 1979.

Tüzer, Abdüllatif, Dinî Tecrübe ve Mistisizm: Felsefî Bir Yaklaşım, İstanbul: Dergah Yayınları, 2006.

Underhill, Evelyn, Mysticism: A Study in Nature and Development of Spiritual Consciousness, London: Methuen University Paperbacks, 1960.

Wainwright, Wm. J., “Stace and Mysticism”, The Journal of Religion, 50/2 (1970): 139-54.

Yalçın, Sahabettin, “Kant’ta Transandantal Ben Bilinci”, Felsefe Dünyası, 39/11 (2004): 39-71. 


\section{Mistisizmin Felsefî Okuması: Walter T. Stace'in Mistik Tecrübeye İlişkin Dü- şüncelerinin Bir Değerlendirmesi}

Bu makale, mistisizm konusunda XX. yüzyılın öne çıkan isimlerinden biri olan Walter T. Stace'in konuya ilişkin düşüncelerinin değerlendirmesini içermektedir. Stace, Kant sonrası dinin kaynağı, Tanrı’nın varlığı, dinî tecrübenin imkânı gibi tartışmalar bağlamında gündeme gelen mistisizmin felsefî okumasını yapar. Tecrübeyi dinden bağımsızlaştırarak insanın doğasıyla ilgili bir probleme dönüştürür. Mistik metinlerin fenomenolojik incelmesiyle, mistik tecrübenin bir türünün, "içe dönük mistik tecrübe"nin "saf bilinç" tecrübesi olduğunu ve tecrübe esnasında "evrensel ben" ile dolaysız birliğin tecrübe edildiğini iddia eder. Ardından mistisizmle ilgili pek çok soruna bu iddia temelinde cevaplar sunar. Ancak dikkatli bir okuma ile Stace'in açıklamalarının doğrudan mistik metinlerin fenomenolojik okumasına dayanmadığı, tecrübenin tanımı ve sınıflandırmasının gerisinde bilinçle ilgili felsefî bir varsayımın yer aldığı ortaya çıkar. Aslında Stace, Kant’ın düşünce dizgesinde yer alan tecrübenin unsurlarını önceleyen "aşkınsal ben"i kabul ederek, mistik tecrübeyi "aşkınsal ben" in tecrübesi olarak yorumlar. Fakat Stace, "aşkınsal ben” ve saf bilinç ile ilgili düşüncelerini temellendirmez. Kant’a yaptığ atıflarını belirginleştirmez. Bunun yerine dikkatleri mistik anlatılar üzerine çeker. Mistiklerin kullandıkları benzer kelimeleri vurgulayarak, bunları "saf bilinç tecrübesi”ne delil gösterir. Bu tutumu, argümanının felsefî temellerinin zayıf kalmasına ve birtakım muğlaklıkların oluşmasına yol açar. Bu makalede çoğu defa dikkatten kaçan bu noktaların altının çizilmesi amaçlanmaktadır.

Anahtar kelimeler: Walter T. Stace, mistik tecrübe, birlik, saf bilinç, aşkınsal ben. 